Discharge and

Flow Distribution,

Columbia River Estuary

GEOLOGICAL SURVEY PROFESIONAL PAPER 433-P

Prepared in cooperation with the

U.S. Atomic Energy Commission

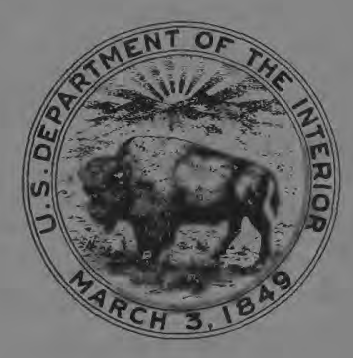




\section{Discharge and}

Flow Distribution,

\section{Columbia River Estuary}

By G. A. LUTZ, D. W. HUBBELL, and H. H. STEVENS, JR.

TRA N P OR T OF R A I O U C L I D S B Y S T R E A S

GEOLOGICAL SURVEY PROFESSIONAL PAPER 433-P

Prepared in cooperation with the

U.S. Atomic Energy Commission

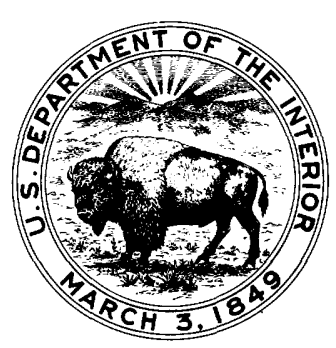

UNITED STATES GOVERNMENT PRINTING OFFICE, WASHINGTON : 1975 


\section{UNITED STATES DEPARTMENT OF THE INTERIOR}

\section{GEOLOGICAL SURVEY}

\section{E. McKelvey, Director}

Library of Congress Cataloging in Publication Data

Lutz, Garson Alvin, 1913-

Discharge and flow distribution, Columbia River Estuary.

(Transport of radionuclides by streams)

(Geological Survey Professional Paper 433-P)

Bibliography: p.

Supt. of Docs. no.: I 19.16:433-P

1. Stream measurements-Columbia River estuary, Or. and Wash. 2. Columbia River estuary, Or. and Wash. 3. Stream measurements-Mathematical models.

I. Hubbel, David Wellington, 1925- joint author. II. Stevens, Herbert Humphreys, 1927- joint author. III. United States Atomic Energy Commission. IV. Title. V. Series. VI. Series: United States Geological Survey Professional Paper 433-P QE75.P9 no. 433-P [GB1227.C6] 557.3'08s [551.4'83'09797] 75-619061

For sale by the Superintendent of Documents, U.S. Government Printing Office

Washington, D.C. 20402

Stock Number 024-001-02214-1 


\section{CONTENTS}

\begin{abstract}
_- - - - - - - - - - - - - - - - - - - - - - - - - -
Introduction and acknowledgments

Generalized description of the estuary

Discharge-measurement equipment and techniques _..--

Mathematical-model theory _._-

Development of mathematical models _.

Beaver Army Terminal reach _-_-

Calibration procedure

Mathematical-model discharge results _-_- - - -

Astoria reach _...-.

Calibration procedure
\end{abstract}

\begin{tabular}{r|rr} 
Page & Page \\
P1 & Development of mathematical models - Continued & \\
1 & Astoria reach - Continued & P17 \\
3 & Mathematical-model discharge results & 19 \\
3 & Flow characteristics in the lower estuary & \\
6 & Lateral circulation at the discharge-measuring cross & 19 \\
7 & section, Astoria reach $-1-0$ & \\
8 & Flow-predominance patterns at the discharge-measuring & \\
8 & cross section, Astoria reach & 19 \\
10 & Flow-predominance patterns in the south channel, & \\
11 & CRM 5.6-22.5 & Summary - \\
13 & References cited &
\end{tabular}

\section{ILLUSTRATIONS}

FIGURE 1. Map showing location of the lower Columbia River and estuary

2. Graphs showing observed vertical distributions of salinity, normal velocity, and flow direction at CRM 14 at various times in tidal cycles during periods of high and moderate upland flows _

3. Photograph showing velocity-azimuth-depth assembly

4. Photograph showing data-acquisition system

5. Definition sketch of an element of channel

6. Map of Beaver Army Terminal reach, showing cross sections where channel geometry was defined

7. Graph showing variation of the flow-resistance coefficient with daily mean discharge, Columbia River at Beaver Army

Terminal near Quincy, Oreg.

8. Map of Astoria reach, showing cross sections where channel geometry was defined _

9-11. Graphs showing:

9. Change in $\eta / \eta_{\min }$ with relative time at Astoria, Oreg.

10. Comparison between measured and computed discharges for low instantaneous discharges at Astoria, Oreg., on April 13, $1970 \ldots$

11. Comparison between measured and computed discharges for high instantaneous discharges at Astoria, Oreg., on March 7, $1970 \ldots \ldots$

12. Hydrographs showing daily mean discharges at Beaver Army Terminal and Astoria, Oreg., May-September 1968

13-15. Graphs showing:

13. Vertical distribution of flow predominance in the "north," middle, and south channels at the measuring cross section at Astoria, CRM 14, for various mean discharges

14. Variation of flow predominance with mean discharge at the measuring cross section at Astoria, CRM 14

15. Graph showing flow predominance along the longitudinal axis of the south channel during a half tidal cycle - - - - - - - - - - - - - - - - - - - - ----------------------1

16-17. Graphs showing salinity distribution along the longitudinal axis of the south channel at various times in the tidal cycle on:

16. September 14,1969

17. May 23, 1970

18. Graph showing percentage error in computed instantaneous discharge at Astoria, Oreg., plotted against comparable measured discharge 


\title{
TABLES
}

TABLE 1. Summary of discharge measurements at Beaver Army Terminal near Quincy, Oreg.

2. Areas and top widths of average cross sections representative of the two subreaches in the Beaver reach

3. Areas and top widths of average cross sections representative of the two subreaches in the Astoria reach

4. Summary of discharge measurements at Astoria, Oreg. -

5. Lateral distribution of ebb and flood discharge in the measuring cross section at Astoria, CRM 14

6. Variation of flow predominance with depth at selected locations in the measuring cross section at Astoria, CRM $14 \quad 20$

7. Error analysis of computed discharges at Astoria, Oreg.

\section{APPENDIXES}

\author{
APPENDIX 1. Daily mean discharge of the Columbia River at Astoria, Oreg. \\ 2. Determination of percentage error between measured and computed discharges at Astoria

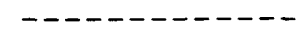

\section{ENGLISH-METRIC CONVERSIONS}

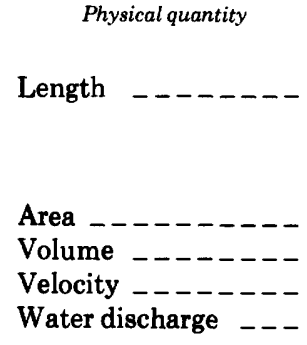

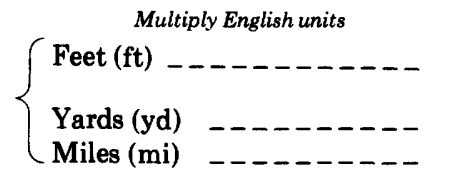

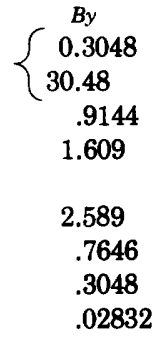

Square miles $\left(\mathrm{mi}^{2}\right)$

Cubic yards $\left(\mathrm{yd}^{3}\right)$

Feet per second (ft/s)

Cubic feet per second $\left(\mathrm{ft}^{3} / \mathrm{s}\right)$
To obtain metric units

Metres (m)

Centimetres (cm)

Metres (m)

Kilometres (km)
Square kilometres $\left(\mathrm{km}^{2}\right)$

Cubic metres $\left(\mathrm{m}^{3}\right)$

Metres per second (m/s)

Cubic metres per second $\left(\mathrm{m}^{3} / \mathrm{s}\right)$ 


\title{
DISCHARGE AND FLOW DISTRIBUTION, COLUMBIA RIVER ESTUARY
}

\author{
By G. A. LuTZ, D. W. HubBell, and H. H. STEvens, JR.
}

\section{ABSTRACT}

Low-level radioactive wastes were discharged into the Columbia. River at the Hanford Reservation, U.S. Atomic Energy Commission, near Richland, Wash., from 1944 until early 1971. The various radionuclides that made up the waste in the river associated with sediment and biota or remained in solution and were subsequently distributed throughout the estuary and into the Pacific Ocean. To provide information on the amount of radionuclides being transported through the estuary, continuous records of water discharge were obtained near both the upper and the lower ends of the estuary during the period 1968-70.

Complex velocity distributions, mainly due to salinity gradients, made it impossible to use conventional methods of measuring discharge in the lower part of the estuary; however, a new technique, MOVD (measurement of velocity distribution by moving boat), was developed for determining the magnitude and direction of the water velocity throughout the entire depth at a vertical. Repetitive measurements at a series of verticals in cross sections at the Beaver Army Terminal, Oreg., Columbia River mile 53.3, and at Astoria, Oreg., Columbia River mile 14, defined flow hydrographs at these locations during half tidal cycles on a number of occasions.

The defined flow hydrographs, in turn, were used to calibrate mathematical models for computing continuous records of discharge. The models, which were necessary mainly because of the influence of the tide, consisted of partial differential equations that were written to express the conservation of mass and momentum in one-dimensional unsteady homogeneous-density open-channel flow and were solved by the method of characteristics.

At Beaver Army Terminal, which is in the freshwater part of the estuary, application of the mathematical model was fairly straight forward, and discharges computed every 15 minutes for May 1968 through June 1970 are considered to be very accurate.

At Astoria, where salinity gradients are present and channel geometry is complex, it was necessary with the model to vary the flow resistance coefficient throughout each ebb and flood period in order to compute discharge hydrographs having the same shapes as the hydrographs defined by measurements. In addition, in order to compute hydrographs that compared closely in magnitude with defined hydrographs, a factor had to be applied daily to adjust measured water-surface slopes that are used in the model. The factor was determined by trial by comparing model discharges with daily mean discharges from a simple volumetric relation based on the daily mean discharge at Beaver Army Terminal and the net daily storage of water between Astoria and Beaver Army Terminal. Monthly mean discharges determined from model discharges computed every 15 minutes from March 1968 through June 1970 by this technique compare closely with monthly mean discharges determined by the routing technique used by the Northwest Water Resources Data Center. Computations show that daily mean discharges at Astoria follow a cyclic pattern; hence, they cannot be used as indicators of the upland freshwater discharge.

When the daily mean discharge at Beaver Army Terminal is less than about $165,000 \mathrm{ft}^{3} / \mathrm{s}$ (cubic feet per second) or $4,670 \mathrm{~m}^{3} / \mathrm{s}$ (cubic metres per second), the south (navigational) channel at Astoria conveys proportionately more flow during the ebb than during the flood, and the remainder of the cross section conveys proportionately more flow during the flood than the ebb. This produces a net clockwise circulation of water between the two channels. For daily mean discharges from about 165,000 to $190,000 \mathrm{ft}^{3} / \mathrm{s}\left(4,670\right.$ to $\left.5,380 \mathrm{~m}^{3} / \mathrm{s}\right)$, there is a net counterclockwise circulation, and for those over $190,000 \mathrm{ft}^{3} / \mathrm{s}(5,380$ $\mathrm{m}^{3} / \mathrm{s}$ ) the circulation also is clockwise.

In the north channel at Astoria, flow near the bottom is predominantly landward for mean discharges at the measurement cross section less than about $340,000 \mathrm{ft}^{3} / \mathrm{s}\left(9,630 \mathrm{~m}^{3} / \mathrm{s}\right)$, whereas flow in the upper layers is predominantly seaward for all discharges. The pattern in the south (navigational) channel is roughly similar to that in the north channel, but in the middle channel the flow-predominance pattern is more complex.

In the navigational channel on September 14, 1969, when the daily mean discharge at Astoria was $208,000 \mathrm{ft}^{3} / \mathrm{s}\left(5,890 \mathrm{~m}^{3} / \mathrm{s}\right)$, saltwater reached Columbia River mile 22 and the flow was predominantly seaward for all depths upstream from Columbia River mile 17.5. Downstream from that point, flow in the lower half of the depth was predominantly landward, whereas flow in the upper half was predominantly seaward. However, on May 23, 1970, when the daily mean discharge at Astoria was $437,000 \mathrm{ft}^{3} / \mathrm{s}\left(12,400 \mathrm{~m}^{3} / \mathrm{s}\right)$, seawater reached only Columbia River mile 14, and the flow was predominantly seaward throughout the entire study reach, which extended from Columbia River miles 5.6 to $\mathbf{1 6 . 2}$.

\section{INTRODUCTION AND ACKNOWLEDGMENTS}

Low-level radioactive wastes were discharged into the Columbia River at the Hanford Reservation, U.S. Atomic Energy Commission, near Richland, Wash. (fig. 1), from the time of the initiation of nuclear-reactor operations in 1944 until early in 1971. The wastes resulted primarily from the neutron activation of chemical constituents in treated Columbia River water that was used to cool the nuclear reactors. Once the radionuclides were released to the river environment, they remained in solution or became associated with 


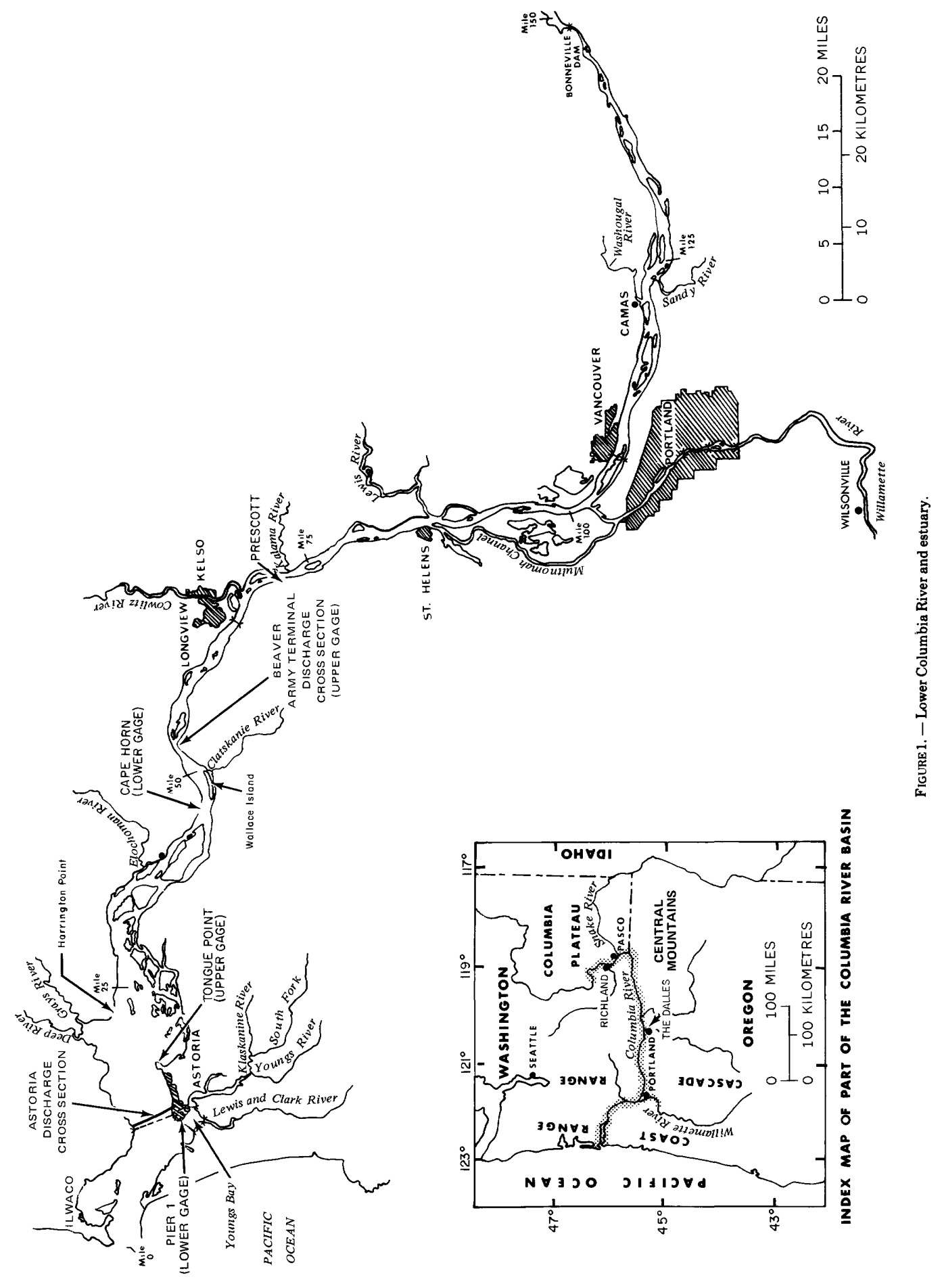


sediment or stream biota. Although much of the radioactivity decayed, some radionuclides were transported by the associated media downstream and ultimately reached the Columbia River estuary and, thence, the Pacific Ocean.

In late 1963 the U.S. Geological Survey undertook, in cooperation with the U.S. Atomic Energy Commission, an investigation of the movement of radionuclides in the Columbia River estuary downstream from CRM 65.8 (Columbia River mile) at Longview, Wash. (fig. 1). One of the purposes of the investigation was to define rates of transport of radionuclides at cross sections along the longitudinal axis of the estuary. To accomplish this end, it was necessary to obtain continuous records of total water discharge at the cross sections of interest. This report briefly describes the equipment and techniques used to obtain measurements of the flow, discusses the mathematical models utilized to determine discharges at two different cross sections, presents discharge data, and suggests the nature of circulation patterns in the vicinity of Astoria, Oreg., CRM 14.

In the early phases of the investigation, Chintu Lai aided in the selection of the farthest upstream reach, which is in the vicinity of the former Beaver Army Terminal, Oreg., CRM 53.3 (fig. 1), and prepared a computer program for processing data obtained during discharge measurements in the field. E. A. Prych contributed substantially to the physical installation of water-stage recording equipment utilized throughout the investigation, to the development of the dischargemeasuring system, and to some of the early techniques for processing measurement data.

\section{GENERALIZED DESCRIPTION OF THE ESTUARY}

The Columbia River estuary receives freshwater flow from throughout a drainage area of $259,000 \mathrm{mi}^{2}(671,000$ $\mathrm{km}^{2}$ ). Based on long-term records at The Dalles, Oreg., CRM 189 (U.S. Geological Survey, 1971), the flow at Vancouver, Wash., CRM 107 (fig. 1), averages about $200,000 \mathrm{ft}^{3} / \mathrm{s}\left(5,660 \mathrm{~m}^{3} / \mathrm{s}\right)$. During $1963-70$ daily mean discharges at Vancouver ranged from 78,900 to 675,000 $\mathrm{ft}^{3} / \mathrm{s}\left(2,230\right.$ to $19,100 \mathrm{~m}^{3} / \mathrm{s}$; U.S. Geological Survey, 1971).

Tides of the mixed-type characteristic of the Pacific coast, two high waters and two low waters during a 24.8hour period, produce landward (upstream) flows in the estuary that have been measured as far upstream as Prescott, Oreg., CRM 72 (U.S. Geological Survey, 1970). At the mouth, CRM 0, the mean tidal range (U.S. Coast and Geodetic Survey, 1969 , p. 172-173) is 5.6 feet (1.7 $\mathrm{m})$, and the diurnal range is 7.5 feet $(2.3 \mathrm{~m})$. Tide ranges are amplified somewhat within the estuary and are a maximum in the vicinity of Youngs Bay, CRM 12 (fig. 1 ); the mean and diurnal tide ranges at this location are 6.7 and 8.6 feet $(2.0$ and $2.6 \mathrm{~m})$, respectively. In the vicinity of the Beaver Army Terminal, Oreg., CRM 53.3, the mean the diurnal tide ranges are approximately 4.3 and 5.2 feet $(1.3$ and $1.6 \mathrm{~m})$, respectively. During periods of low and moderate runoff, tides influence flow in the Columbia River as far upstream as Bonneville Dam, CRM 145 (fig. 1); at Vancouver, CRM 107, the tidal influence persists for all flows to as much as 500.000 $\mathrm{ft}^{3} / \mathrm{s}\left(14,200 \mathrm{~m}^{3} / \mathrm{s}\right)$.

The combination of moderate tide ranges and a large freshwater discharge produces a dynamic environment within the estuary. At low upland flows, cold saline water from the ocean intrudes as far upstream as Harrington Point, Wash., CRM 23 (fig. 1). At times of high upland flow, salinity intrusion is limited to the lower part of the estuary. For instance, on May 23, 1970, when the daily mean discharge through the cross section at CRM 14 was about $437,000 \mathrm{ft}^{3} / \mathrm{s} \quad\left(12,400 \mathrm{~m}^{3} / \mathrm{s}\right)$, measurable salinities extended upstream only to about CRM 14. As a result of the wide variation in the patterns of salinity intrusion, salinity gradients in the three coordinate directions vary significantly throughout the year. According to the classification of Pritchard (1955), the Columbia River estuary is in the general category of a coastal-plain estuary that exhibits characteristics most of the time of a type-B (partly mixed) estuary.

Velocity distributions in both the vertical and lateral directions vary significantly with time as a result of tidal motion, large freshwater discharges, and salinity (density) gradients. Several observed velocity distributions in the vertical direction are shown in figure 2 . The lack of uniformity, with time and position, in the distribution of velocity complicates the definition of flow and necessitates detailed velocity measurements in both the vertical and lateral directions.

\section{DISCHARGE-MEASUREMENT EQUIPMENT AND TECHNIQUES}

In order to define the temporal variation of discharge through a cross section in the estuary it is necessary to define both the vertical and lateral distributions of velocity by repetitive measurements throughout the tidal cycle. Because of the cycle changes in velocity with time, it is essential that individual velocity measurements be obtained rapidly. A unique measuring system suitable for operation on a continuously moving boat was developed (Prych and others, 1967) to meet this requirement. With the system, the magnitude and direction of water velocities relative to the boat are measured throughout the depth with a modified version of a VADA (velocity-azimuth-depth assembly) unit (Lockett and Kidby, 1961; Barron, 1963) that is fitted with a modified Ott cosine-propeller current meter (fig. 3 ). Concurrently, the heading, the speed over the bottom, and the drift angle of the boat are determined from a compass and an 


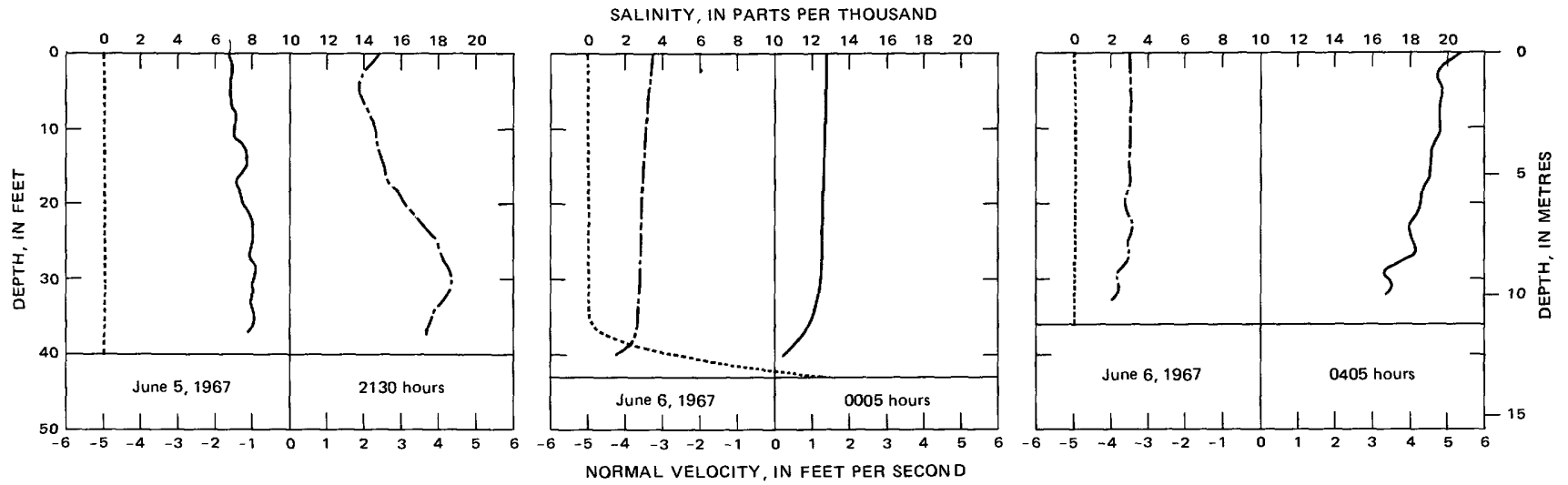

NORMAL VELOCITY, IN FEET PER SECOND

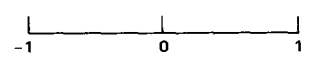

NORMAL VELOCITY, IN METRES PER SECOND
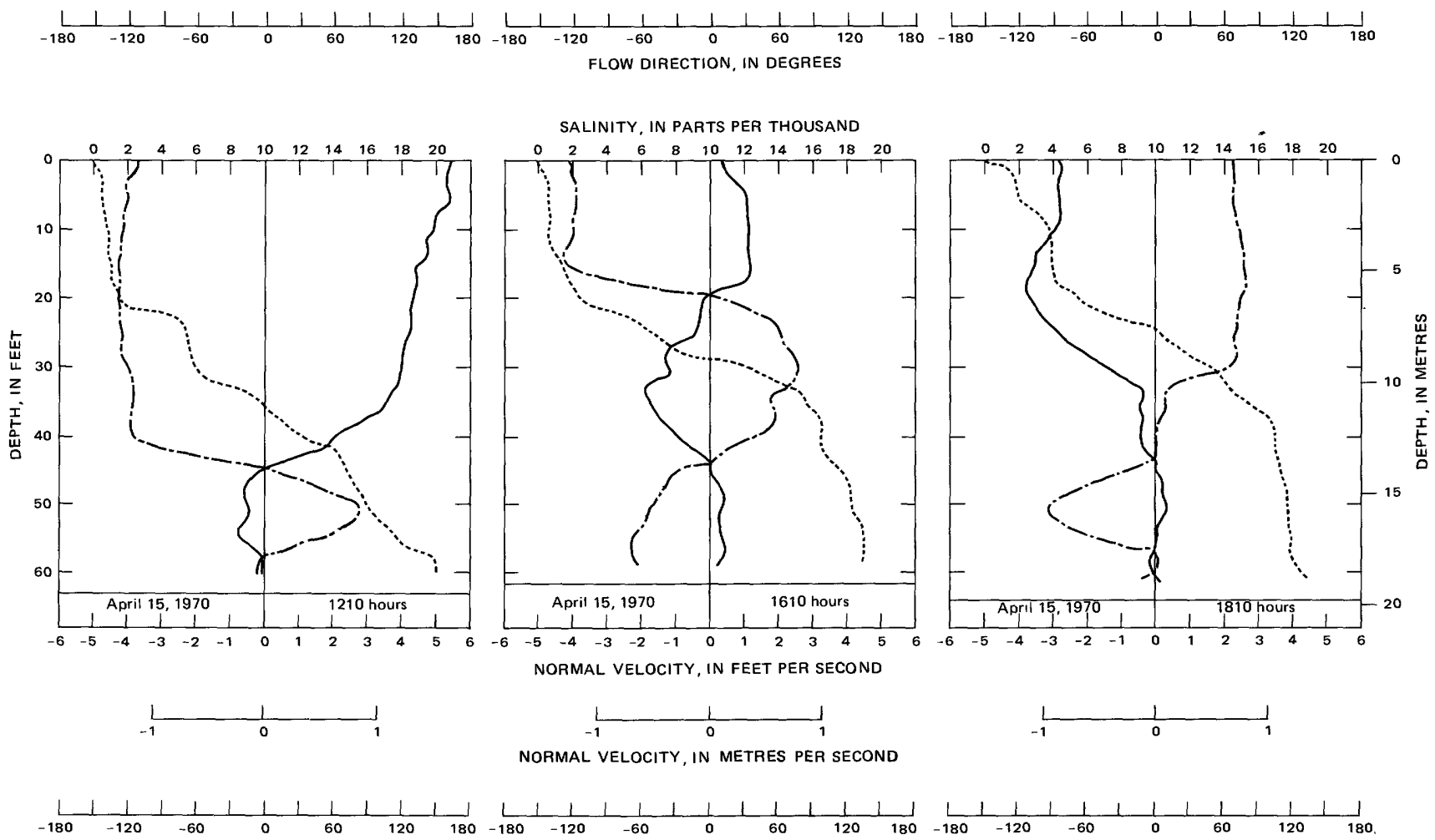

NORMAL VELOCITY, IN METRES PER SECOND
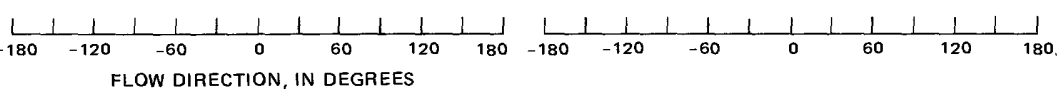

EXPLANATION

Normal velocity

Flow direction

FiguRE 2. - Observed vertical distributions of salinity, normal velocity, and flow direction at CRM 14 at various times in tidal cycles during periods of high (June 1967) and moderate (April 1970) upland flows. Indicated normal velocities are components normal to the measurement cross section of absolute velocity vectors; negative values designate upstream flow. Flow directions give the angle of approach of the

on-board sonic navigation unit. Outputs from all sensors, including the velocity meter, are analog signals that either are or can be displayed visually on strip-chart recorders (fig. 4), and all signals are sampled on command, virtually instantaneously, by a moderately high flow to the cross section; positive and negative values pertain to angles measured clockwise and counterclockwise, respectively, from the southward heading of the cross section; hence, an angle of $-90^{\circ}$ indicates downstream flow normal to the cross section. Tide height during each set of distributions can be deduced by considering the bottom (solid horizontal line) to be at a fixed elevation.

speed scanning digital voltmeter. Voltages, in turn, are recorded (fig. 4) on magnetic tape (except the signal from the depth transducer that indicates the height of the VADA unit above the bed; this signal is recorded only as an analog signal on strip chart). 


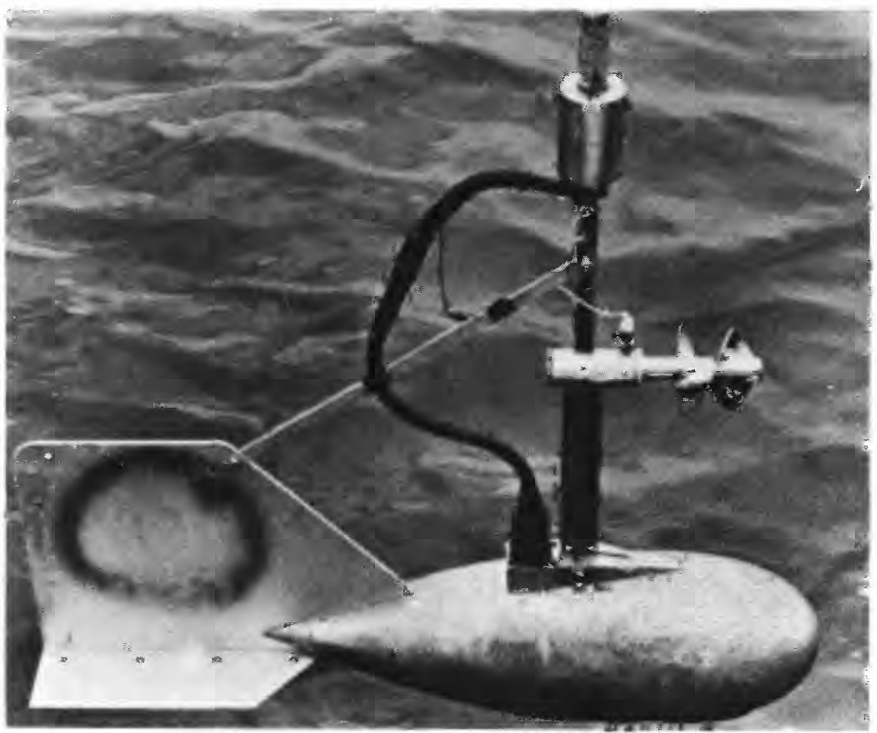

Figure 3. - Velocity-azimuth-depth assembly (from Prych and others, 1967).

For the definition of the velocity distribution at a vertical, the boat is positioned and kept as stationary as possible by heading into the current and using power. Ordinarily, an attempt is made to maintain slight headway during the measurement. The VADA unit is lowered to within 2 to 3 feet $(0.6$ to $0.9 \mathrm{~m})$ of the streambed, allowed to stabilize, and then raised slowly to the surface. The vertical velocity of the unit is regulated so that the angle of attack of the water relative to the meter is less than $20^{\circ}$. During the upward traverse, the analog signals are sampled and recorded every 3 seconds. Later, the recorded data (relative speed and direction of the current, absolute speed and drift angle of the boat, and boat heading) are combined by vector addition, using a digital computer, to yield the absolute velocity (speed and direction) of the current at each data point throughout the depth.

Discharge is measured by observing the entire velocity profile at a series of verticals along a cross section. Ordinarily, measurements are made at about 20 verticals during each traverse of the cross section. As soon as a traverse is completed, the boat is moved to the opposite side of the estuary, and the measurement sequence is repeated. The exact location of each measurement vertical is determined by triangulation with hydrographic sextant; hence, measurement sequences can only be made during daylight hours.

For the computation of discharge, the velocity component normal to the cross section at each data point in a vertical is used to calculate a discharge per unit width for the increment of depth represented by the point. The incremental discharges are summed over the depth to give a discharge per unit width for the entire vertical. The discharge for the section represented by the vertical

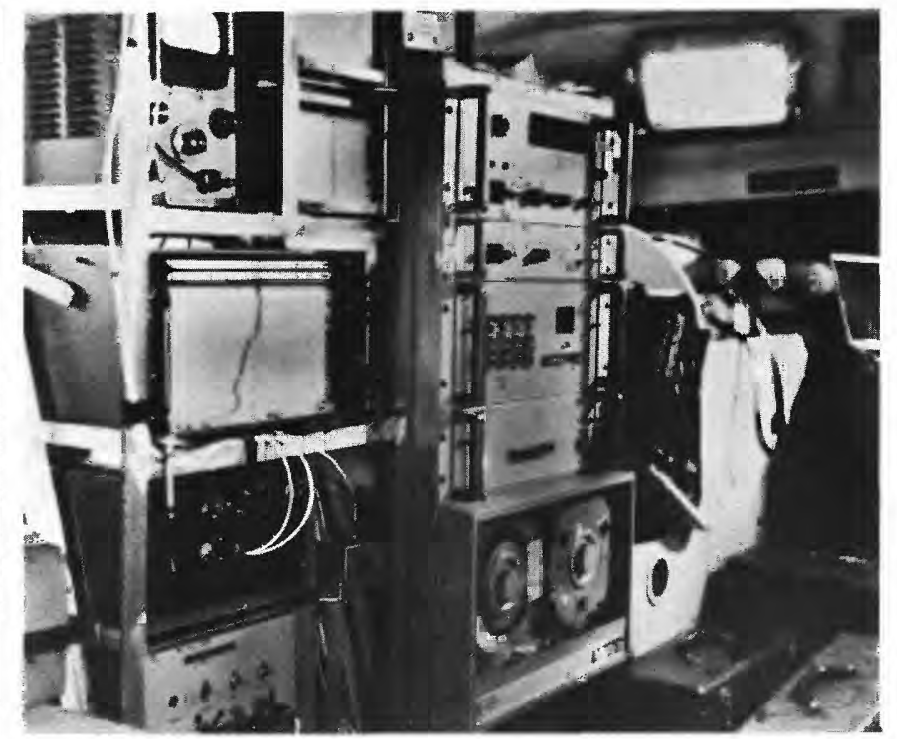

FIGURE 4. - Data-acquisition system. The strip-chart recorders provide continuous real-time displays of sensor signals, and the magnetic-tape unit digitizes data for computer processing.

is determined by multiplying the section width, which is computed according to the standard midsection method, by the discharge per unit width for the vertical. Because discharge changes rapidly with time, section discharges are not summed to give a total discharge; rather, the cross section is divided into several parts and the discharge through each part is determined by summing the section discharges within the part. Hydrographs are then obtained by plotting the discharge for each part against the corresponding mean times when the verticals were measured. The total discharge hydrograph is defined by summing the hydrographs for the individual parts.

In addition to this "standard" method, which hereinafter will be called the MOVD (measurement of velocity distribution by moving boat) method, discharge measurements sometimes were made at the Beaver Army Terminal cross section by a modification of the moving-boat technique developed by Smoot and Novak (1969). With the Smoot-Novak method, a boat is traversed across the width of the measuring section by "crabbing" along a range line that is normal to the flow direction. During the traverse, a current-meter-vane unit, which is mounted to the boat 3 to 4 feet $(0.9$ to 1.2 $\mathrm{m}$ ) below the water surface by a rod and angle-indicator assembly, freely and continuously alines in a direction parallel to the vector sum of the lateral velocity of the boat and the velocity of flow. Periodically noting the current-meter velocity and the vane direction permits the velocity of flow normal to the cross section at the current-meter depth, $V$, to be determined at a series of data points across the width from

$$
V=V_{V} \sin \alpha,
$$


where

$V_{V}$ is the instantaneous flow velocity relative to the boat as measured by the current meter;

and

$\alpha$ is the complementary angle between the crosssection line and the current-meter direction.

The lateral positions of the data points, where depth as well as velocity and current-meter direction are observed, are established each time the filament of water passing the current meter reaches a preselected length, $L_{V}$. That is, observations are made whenever the current meter has turned a preselected number of revolutions. (Because the relationship between velocity and rate of rotation of the current meter is linear, a given number of revolutions is equivalent to a particular filament length.) If the flow is normal to the cross section, the width between data points, $L_{B}$, equals $L_{V} \cos \alpha$. Section discharges are computed by the standard midsection method from values of $V, L_{B}$, and the depth, $d$. Total discharge is obtained by correcting (multiplying) the sum of the section discharges by (1) a width-correction factor, which is the ratio of the measured width to the sum of the computed section widths (this factor adjusts for variations in boat course and for variations in the flow direction relative to cross section), and by (2) a velocity-correction factor, which is the ratio of the mean velocity in a vertical to velocity at the current-meter depth (this ratio is determined from detailed velocity-distribution data at several verticals).

The modified technique used at the Beaver Army Terminal is essentially the same as the Smoot-Novak method; however, it was designed to permit use of the VADA and the navigation units. During the lateral traverse, the VADA unit was suspended 15 feet $(4.6 \mathrm{~m})$ below the water surface and lateral data points were established at 10-yard $(9.1-\mathrm{m})$ intervals as indicated by the navigation unit. All variables were measured in the same way as in the MOVD method, and the velocity of flow normal to the cross section at the 15 foot $(4.6-\mathrm{m})$ level was determined by vector addition in the same way as in the MOVD method. The widths between data points, except the sections adjacent to the shores, were assumed to be constant and were determined by dividing the measured width between the first and last stations by one less than the total number of data points. Section discharges were computed by the midsection method and summed to give a total discharge. This total was altered by a velocity-correction factor that, in effect, adjusted the velocity at the 15 -foot $(4.6-\mathrm{m})$ level to represent the mean velocity in the vertical. The factor, $c$, was determined as

where

$$
c=0.82(d / y)^{0.2},
$$

$y$ is the height of the velocity meter above the bed, by assuming (1) the parabolic velocity-distribution law

$$
\begin{aligned}
& \text { where } \\
& V_{y} \text { is the velocity at a height, } y \text {; } \\
& C \text { is a constant for given conditions ( } C \text { cancels in } \\
& \text { the derivation of } c \text { ); and } \\
& n \text { is a constant assumed to be equal to } 5.0 \text { for a } \\
& \text { rough boundary (Savini and Bodhaine, 1971, } \\
& \text { p. 12), }
\end{aligned}
$$

and (2) the condition that the mean velocity, $\bar{V}$, in the vertical occurs at $y=0.368 \mathrm{~d}$. The correction factor, $c$, was applied as a constant for all verticals by taking $d$ equal to the mean depth in the cross section and $y$ equal to the mean depth minus 15 feet $(4.6 \mathrm{~m})$.

\section{MATHEMATICAL-MODEL THEORY}

Whenever unsteady flow conditions exist, such as in an estuary, a unique relation between water-surface elevation (stage) and discharge does not exist, and continuous records of discharge cannot be obtained by conventional methods of discharge computation. In 1961, Baltzer and Shen developed a mathematical model for computing discharge for unsteady flow conditions. Two other methods for computing discharges for unsteady flow conditions have been developed by Lai (1965a; 1965b). All three mathematical models are based on the equations of continuity and motion expressed in one spatial dimension and simplified by approximations to represent open-channel flow.

The equation of continuity, or conservation-of-mass equation, states that the net change in discharge in a reach is equal to the change in storage in the reach that is (fig. 5 , definition sketch),

mass in - mass out + side inflow $=$ increase of mass within the reach,

or

$$
\rho A u-\left[\rho A u+\frac{\partial(\rho A u)}{\partial x} \Delta x\right]+\rho q \Delta x=\rho B \frac{\partial Z}{\partial t} \Delta x
$$

where

$\rho$ is the density of water;

$A$ is the channel cross-section area;

$u$ is the flow velocity in the longitudinal direction;

$Z$ is the elevation of water surface;

$t$ is time;

$q$ is the lateral inflow per unit length;

$x$ is a distance measured along the $x$ axis; and

$B$ is the top width of the cross section.

The equation of motion, or conservation-ofmomentum equation, states that the resultant force acting on an element of water in a given direction is equal to the time rate of change of momentum of the water contained in the element. Applying Newton's Law 

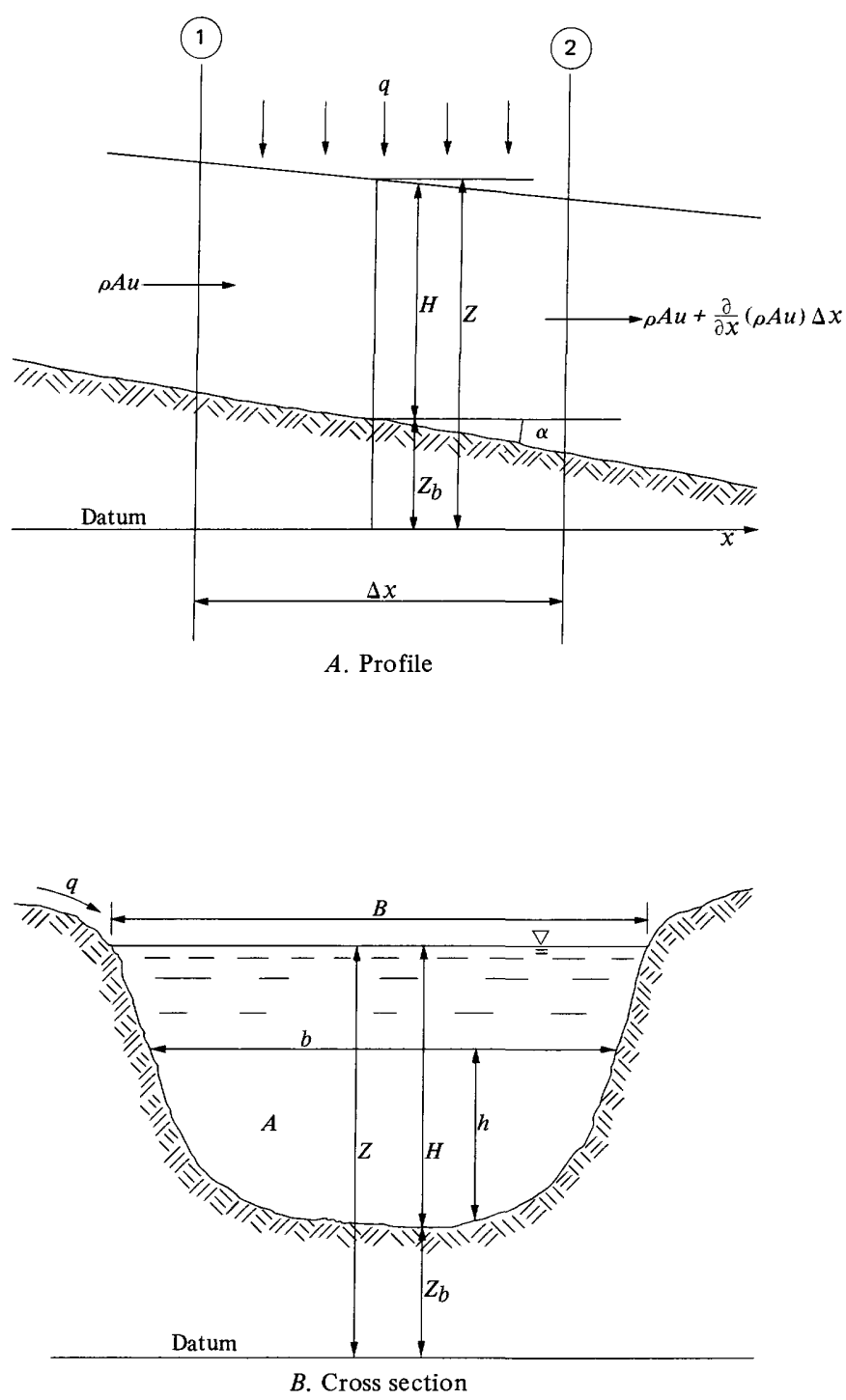

FIGURE 5. - Definition sketch of an element of channel (from Lai, 1965a). See text for description of symbols.

of momentum, the equation of motion can be obtained as

$$
\frac{\partial u}{\partial t}+u \frac{\partial u}{\partial x}+g \frac{\partial Z}{\partial x}+g \frac{k}{R^{4 / 3}} u|u|+\frac{q u}{A}=0
$$

where

$g$ is acceleration due to gravity;

$R$ is the hydraulic radius; and

$k$ is a parameter depending on the flow-resistance coefficient, $\eta$ which is similar to Manning's $n$.

The assumptions made in the derivation of the above two basic partial differential equations for describing unsteady flow are (1) the flow is moderately unsteady, (2) the fluid is of homogeneous density, (3) the channel is prismatic and has a very mild bottom slope, (4) the velocity of flow is uniform over the cross section, (5) the variables in the equations and their derivatives are continuous functions with respect to distance and time, and (6) the flow-resistance coefficient is the same as that for steady flow and, hence, can be approximated from the Chézy or Manning formulas.

Because an explicit analytical solution for the set of partial differential equations is not possible, Baltzer and Shen (1961) developed a power-series method of solution. The method is based on a Maclaurin-series expansion of the two equations about a reference point along the waterway at a given instant in time. The expansion is made in terms of the stage at the reference point and the associated stage at a nearby point, and then it is rewritten in finite-difference form with respect to time in order to obtain the change in discharge during a finite increment of time; discharge is computed from appropriate boundary conditions in a stepwise manner throughout time. Lai (1965a) developed another means of solution by applying the method of characteristics which transforms the basic partial differential equations into four ordinary differential equations. These four equations are treated as finite-difference equations for which unique solutions of the flow at successive times are readily possible with the known boundary conditions. He also (Lai, 1965b) utilized the implicit method in which the two basic partial differential equations are directly transformed into corresponding finite-difference equations; by setting up as many equations as there are unknown dependent variables, the equations are solved simultaneously for all unknowns at the advanced (or forward) time level, using the appropriate boundary conditions, to obtain flow at subsequent times.

The three methods of computing discharges for unsteady flow conditions are designed for use on high-speed digital computers. All three methods have produced accurate results in the freshwater parts of tide-affected streams or in well-mixed tidal estuaries (Baltzer and Lai, 1968); however, depending on the physical properties of the site, one method may be more appropriate than the others.

Recently, two-dimensional flow models have been developed to account for variations in either the lateral or vertical directions, as well as in the longitudinal direction. These models usually must be solved with extensive quantities of input data and by using computers having extremely large core memory. Also, like the onedimensional models, they represent flow in well-mixed estuaries and are not adequate to describe complicated saltwater circulation.

\section{DEVELOPMENT OF MATHEMATICAL MODELS}

To meet the need for radionuclide and suspendedsediment transport rates through the upper and lower 
parts of the estuary, measurement cross sections where discharges would be defined were established at Beaver Army Terminal and at Astoria (fig. 1). At both these locations tides produce unsteady flow; hence, the most feasible means for obtaining records of water discharge was to apply transient-flow models. When data collection for discharge determinations began in 1966, only one-dimensional models, as previously described, were available, and computer memory systems were relatively limited. As a result, the field program was designed to provide essential data for only the one-dimensional approach.

Physical conditions at the Beaver Army Terminal can be represented moderately well by a one-dimensional model; however, at Astoria, significant salinity gradients and complex flow patterns introduce serious deviations from one dimensionality. Because of the differences, the development and application of the model for each location was substantially different.

In order to adapt and use on a continuous basis any of the three mathematical models previously described, certain boundary values and other data are required. Boundary values include (1) frequent periodic simultaneous stages at the extremities of a reach that is sufficiently long to permit the accurage determination of the fall (water-surface slope), yet is not so long as to violate limitations implicit in the mathematical solutions; and (2) for all stages, values of the channel width, depth, and area that are representative of the reach. In addition, reach length and inflow or outflow within the reach must be known, and actual hydrographs of discharge at a cross section in the reach (preferably at oner end) must be abailable to define parameters of the model.

\section{BEAVER ARMY TERMINAL REACH}

The Beaver Army Terminal (hereinafter referred to as "Beaver") is a deactivated military reservation located on the Oregon side of the Columbia River at CRM 53.3 (fig. 1). The cross section at Beaver is at one of the narrowest parts of the estuary (about $2,300 \mathrm{ft}$, or $700 \mathrm{~m}$, wide), is devoid of any islands or extensive flats, is reasonably uniform in depth, and has a fairly uniform lateral velocity distribution. As such, it is an excellent measurement and sampling section. To develop a mathematical model of discharge at Beaver, two sites had to be selected for the collection of water-stage data. The upstream gage was installed on the main wharf at Beaver and the downstream gage was installed at Cape Horn, Wash., CRM 47.6 (fig. 1). Both stations were equipped with digital and graphic water-stage recorders. A-C synchronous motor-driven timers actuated the digital recorders essentially simultaneously (within 30 seconds of each other) every 15 minutes. A float and stilling-well system was used to operate the gage at
Beaver and a "bubble gage" (Barron, 1963) was used at Cape Horn. Because at times the water level within the reach is lower than mean sea level and the digital recorders used require the stage data to be always positive, "MSL $1929 "-10$ feet $(3.048 \mathrm{~m})$ was selected as the gage datum for the reach. The reach between the two gages (fig. 6) includes Wallace Island and surficial areas that are regularly inundated by the tide. However, the reach is relatively straight, and most of the flow is conveyed in the navigational channel.

The geometry of the reach was defined from lateral profile data obtained at 11 cross sections (fig. 6) that were spaced roughly equidistant apart. The configuration of the wetted perimeter of each cross section was determined by sounding depths with a recording fathometer and measuring horizontal distances with the navigation unit in the deep parts of the channel and with a Tellurometer in the shallow parts where only a small skiff could go. The profile above the waterline was defined by using a hand level, level rod, and survey chain. Data from all defined cross sections were combined according to the procedures outlined by Davidian (1964) to provide relations between the water-surface elevation, cross-sectional area, and width for average cross sections representative of the entire reach or of several subreaches. Lengths between sections of the reach were measured along the centerline of the main channel on a U.S. Coast and Geodetic Survey navigation chart of the Columbia River.

Discharge hydrographs were defined just downstream from the upper gage at Beaver by applying the MOVD method and the modified Smoot-Novak method to measure the flow. In order to obtain optimum information, measurements were scheduled so that both a complete ebb and a complete flood period would be defined during the measurement sequence.

Discharge measurements at Beaver began on March 24, 1966, and were concluded on April 1, 1970. During this period, 17 hydrographs of discharge, or a total of 119 individual lateral traverses, were made during varying flow conditions. A summary is given in table 1. Examination of table 1 shows that most of the hydrographs were well defined over a time span of about 10 hours. Those of less than about 8 hours resulted because of equipment malfunction or bad weather conditions. Both occurrences could cause a late start or an early termination of the measurement sequence.

\section{CALIBRATION PROCEDURE}

The term "calibration" in this report refers to the process of determining values for the parameters in a mathematical model that provide the best possible fit between measured discharge hydrographs (hydrographs defined from discharge measurements) and hydrographs computed with the model. To calibrate the 


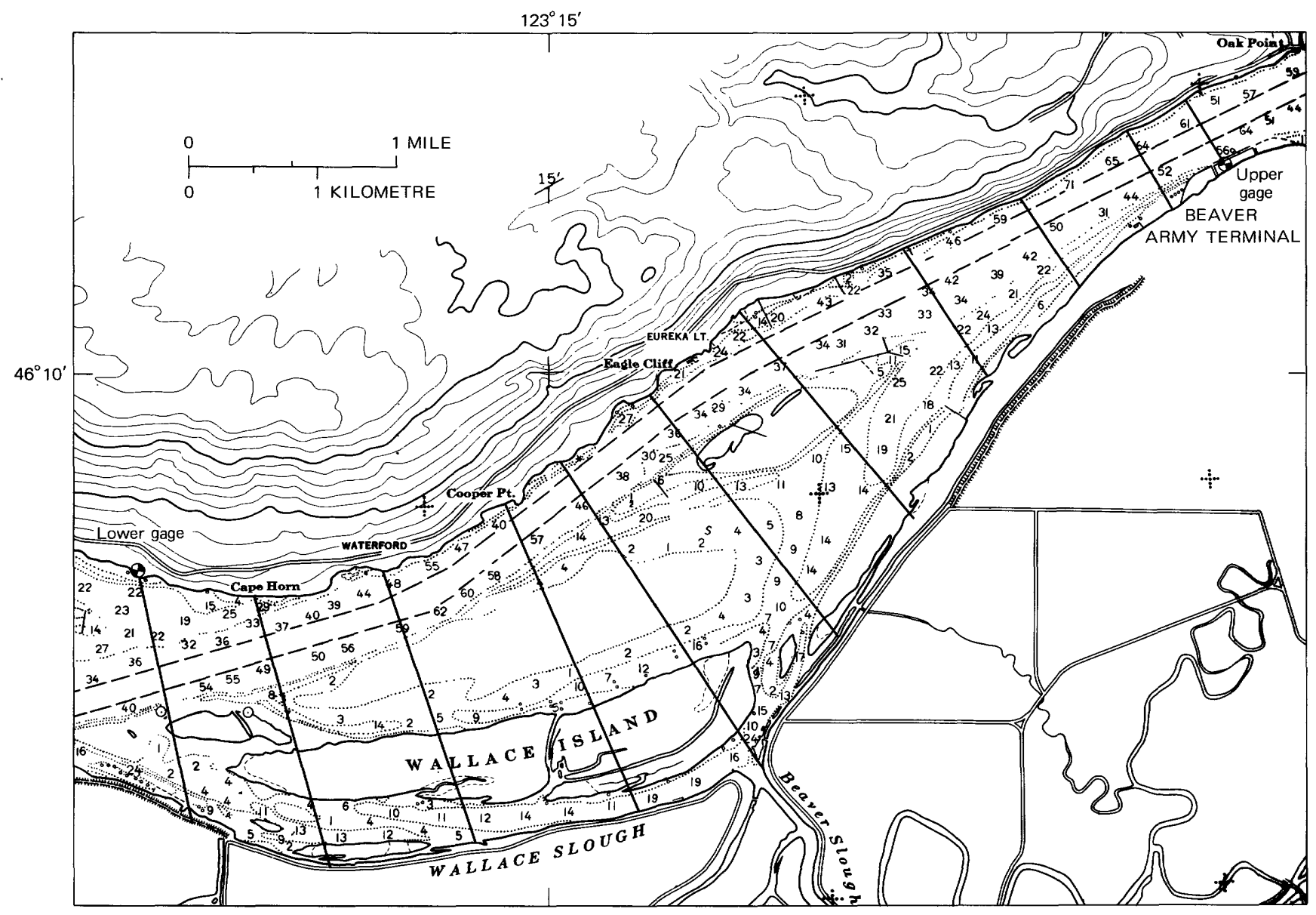

FIGURE 6. - Beaver Army Terminal reach, showing cross sections where channel geometry was defined. Numbers within river boundaries indicate depths, in feet, at Columbia River datum. Base from U.S. Coast and Goedetic Survey; Columbia River Chart 6152, Oregon-Washington, 1968.

TABLE 1. - Summary of discharge measurements at Beaver Army Terminal near Quincy, Oreg.

\begin{tabular}{|c|c|c|c|c|c|}
\hline \multirow[b]{2}{*}{ Date } & & \multicolumn{2}{|c|}{ Number of lateral traverses } & \multirow{2}{*}{$\begin{array}{c}\begin{array}{c}\text { Period of } \\
\text { defined } \\
\text { hydrograph } \\
\text { (hours) }\end{array}\end{array}$} & \multirow{2}{*}{$\begin{array}{c}\text { Daily mean } \\
\text { discharge } \\
\text { at Beaver } \\
\left(\mathrm{ft}^{3} / \mathrm{s}\right)\end{array}$} \\
\hline & & $\begin{array}{l}\text { MOVD } \\
\text { method }\end{array}$ & $\begin{array}{c}\text { Modified } \\
\text { Smoot-Novak } \\
\text { method }\end{array}$ & & \\
\hline $\begin{array}{ll} & 1966 \\
\text { Mar. } & 24 \\
\text { May } & 19 \\
\text { June } & 30 \\
\text { Aug. } & 2 \\
\text { Oct. } & 21\end{array}$ & 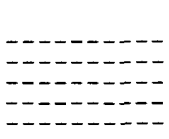 & $\begin{array}{l}6 \\
7 \\
7 \\
6 \\
3\end{array}$ & $\begin{array}{l}0 \\
0 \\
0 \\
0 \\
0\end{array}$ & $\begin{array}{c}9.8 \\
10 \\
10 \\
10 \\
5.3\end{array}$ & $\begin{array}{l}210,000 \\
304,000 \\
306,000 \\
198,000 \\
106,000\end{array}$ \\
\hline $\begin{array}{ll} & 1967 \\
\text { June } & 26 \\
\text { July } & 25 \\
\text { Aug. } & 20 \\
\text { Sept. } & 12\end{array}$ & 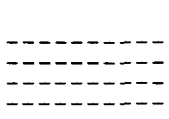 & $\begin{array}{l}0 \\
6 \\
5 \\
4\end{array}$ & $\begin{array}{l}4 \\
1 \\
1 \\
5\end{array}$ & $\begin{array}{c}2 \\
11 \\
9.5 \\
8.3\end{array}$ & $\begin{array}{r}637,000 \\
250,000 \\
130,000 \\
81,000\end{array}$ \\
\hline $\begin{array}{lr} & 1968 \\
\text { Feb. } & 15 \\
\text { May } & 7 \\
\text { July } & 4 \\
\text { Oct. } & 22\end{array}$ & 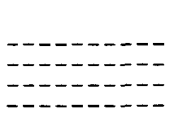 & $\begin{array}{l}2 \\
6 \\
5 \\
5\end{array}$ & $\begin{array}{l}5 \\
3 \\
7 \\
7 \\
7\end{array}$ & $\begin{array}{r}4.5 \\
10.5 \\
11.5 \\
7.3\end{array}$ & $\begin{array}{l}163,000 \\
148,000 \\
299,000 \\
152,000\end{array}$ \\
\hline $\begin{array}{ll} & 1969 \\
\text { Apr. } & 11 \\
\text { June } & 12 \\
\text { July } & 23\end{array}$ & 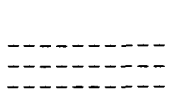 & $\begin{array}{l}0 \\
5 \\
4\end{array}$ & $\begin{array}{l}7 \\
0 \\
3\end{array}$ & $\begin{array}{c}5 \\
10.3 \\
10.5\end{array}$ & $\begin{array}{l}404,000 \\
450,000 \\
181,000\end{array}$ \\
\hline Apr. $\begin{array}{r}1970 \\
1\end{array}$ & -- & 5 & 0 & 8 & 172,000 \\
\hline
\end{tabular}

mathematical models adopted for the Beaver reach values for two parameters had to be determined. The first was the datum correction, which is the factor that is applied to the readings from the two water-stage recorders to adjust the slope to achieve the best fit between measured and computed discharges. The datum correction is the algebraic sum of the absolute difference in elevation between the gage datums (elevation at which the gage reading is zero) and whatever other correction is necessary to obtain accurate discharges with the model. Ordinarily, levels are run between the two gages to evaluate or eliminate any difference between the gage datums; however, because the gages for the Beaver reach were located on opposite banks of the estuary, this was not practicable. Instead, each gage datum was referenced only to the U.S. Coast and Geodetic Survey bench mark located nearest to the gage site, and the required datum correction was determined by trial and error from the model without reference to the magnitudes of the separate elements in the correction. The other parameter that was evaluated is the flow-resistance coefficient, $\eta$. Although the value of $\eta$ is dependent mainly on the flow resistance, it is affected like the datum correction by discrepancies between the mathmatical formulations and actual 
physical conditions. Manning's $n$ can be used as an initial estimate of $\eta$ for a given hydrograph; however, a trial-and-error method of calibration must be used to obtain the final value of $\eta$.

The first attempt at developing a suitable model was made by using the power-series method. However, because the magnitude of the flood and ebb discharges and the general shape of the computed hydrographs did not correspond sufficiently closely to the measured hydrographs, it was concluded that the complex channel geometry precluded treating the Beaver reach as a single entity.

The second method tried was the characteristic method. The advantage of the characteristic method is that discrepancies caused by complex channel geometry can be minimized by dividing the total reach into several subreaches (Lai, 1967). For the Beaver model, the reach was divided into two subreaches. The upper subreach extends from the gage at Beaver downstream to the upstream tip of Wallace Island (fig. 6). This reach is virtually a single channel, although a midchannel bar is periodically exposed at the downstream end. The lower subreach extends from the upstream tip of Wallace Island downstream to the Cape Horn gage. This reach consists of the main river channel and a smaller channel formed by Wallace Island (fig. 6). Extensive flats on the north side of Wallace Island are exposed during periods of low tide. Table 2 lists for various elevations the areas and top widths of cross sections that are representative of the two subreaches and which were computed from data obtained at the 11 cross sections in figure 6 .

Calibration of the model was done by the trial-anderror method. First, by repeated trials with various $\eta$ values, it was found that measured and computed hydrographs compared most consistently when the datum correction was taken as 0.10 foot $(3.0 \mathrm{~cm})$. To correct this condition, 0.10 foot $(3.0 \mathrm{~cm})$ was added to Cape Horn stages. Then, values of $\eta$ that provided the closest comparisons between measured and computed hydrographs were extablished. Figure 7 shows the relationship for the upper subreach between final $\eta$ values and daily mean discharge. For daily mean discharges less than $225,000 \mathrm{ft}^{3} / \mathrm{s}\left(6,370 \mathrm{~m}^{3} / \mathrm{s}\right), \eta$ equals 0.0297 . As the daily mean discharge increases from 225,000 to $430,000 \mathrm{ft}^{3} / \mathrm{s}\left(6,370\right.$ to $\left.12,200 \mathrm{~m}^{3} / \mathrm{s}\right), \eta$ decreases from 0.0297 to 0.0248 . When the daily mean discharge is greater than $430,000 \mathrm{ft}^{3} / \mathrm{s}\left(12,200 \mathrm{~m}^{3} / \mathrm{s}\right), \eta$ equals 0.0248 . For lower subreach, $\eta$ is equal to the $\eta$ value of the upper subreach plus 0.0004 . The causes for the variation in $\eta$ with daily mean discharge were not investigated; however, it seems reasonable that important contributing factors were the variation in the Reynolds number of the flow and the apparent change in the heights and lengths of the bed forms in the channel with discharge.
TABLE 2. - Areas and top widths of average cross sections representative of the two subreaches in the Beaver reach

\begin{tabular}{|c|c|c|c|c|c|}
\hline \multicolumn{3}{|c|}{ Upper Subreach } & \multicolumn{3}{|c|}{ Lower Subreach } \\
\hline $\begin{array}{l}\text { Depth' } \\
\text { (ft) }\end{array}$ & $\begin{array}{c}\text { Top } \\
\text { width } \\
\text { (ft) }\end{array}$ & $\begin{array}{l}\text { Cross- } \\
\text { sectional } \\
\text { area } \\
\text { (sq ft) }\end{array}$ & $\begin{array}{c}\text { Depth' } \\
\text { (ft) }\end{array}$ & $\begin{array}{c}\text { Top } \\
\text { width } \\
\text { (ft) }\end{array}$ & $\begin{array}{l}\text { Cross- } \\
\text { sectional } \\
\text { area } \\
\text { (sq ft) }\end{array}$ \\
\hline $\begin{array}{r}0 \\
2.0 \\
4.0 \\
6.0\end{array}$ & $\begin{array}{l}2,560 \\
2,650 \\
2,730 \\
2,780\end{array}$ & $\begin{array}{l}78,200 \\
83,600 \\
88,800 \\
94,300\end{array}$ & $\begin{array}{l}0 \\
2.0 \\
4.0 \\
6.0\end{array}$ & $\begin{array}{l}2,350 \\
2,400 \\
2,470 \\
2,600\end{array}$ & $\begin{array}{l}73,800 \\
78,500 \\
83,400 \\
88,500\end{array}$ \\
\hline $\begin{array}{r}8.0 \\
10.0 \\
13.0 \\
14.0\end{array}$ & $\begin{array}{l}2,860 \\
2,950 \\
3,090 \\
3,110\end{array}$ & $\begin{array}{r}99,800 \\
105,700 \\
114,800 \\
117,800\end{array}$ & $\begin{array}{l}10.0 \\
12.0 \\
13.0 \\
14.0\end{array}$ & $\begin{array}{l}2,760 \\
2,840 \\
2,890 \\
2,920\end{array}$ & $\begin{array}{r}99,200 \\
104,800 \\
107,700 \\
110,600\end{array}$ \\
\hline $\begin{array}{l}16.8 \\
22.0 \\
24.0\end{array}$ & $\begin{array}{l}3,200 \\
3,320 \\
3,360\end{array}$ & $\begin{array}{l}126,800 \\
143,600 \\
150,300\end{array}$ & $\begin{array}{l}16.0 \\
24.0 \\
---\end{array}$ & $\begin{array}{l}2,980 \\
3,180 \\
---\end{array}$ & $\begin{array}{l}116,500 \\
141,100 \\
----\end{array}$ \\
\hline
\end{tabular}

"Depth of water above gage datum ("MSL 1929" $-10.0 \mathrm{ft}$ ).

\section{MATHEMATICAL-MODEL DISCHARGE RESULTS}

Values of the parameters defined by the calibration, together with appropriate stage data, were used in the model to generate a record of instantaneous discharge every 15 minutes for the period May 1, 1968, through June 30, 1970. Daily mean discharges obtained from this record by algebraically averaging the 96 instantaneous values for each 24 -hour day have been published by the U.S. Geological Survey (1971, p. 275-277). To check the accuracy of the computed discharges, monthly mean discharges determined from the model discharges were compared with monthly mean discharges computed by the Northwest Water Resources Data Center. The method used by the Data Center to obtain a monthly mean discharge was developed by Orem (1968) and is believed to be accurate within 2 or 3 percent. Throughout the period of record, monthly mean discharges from the model consistently compared within \pm 5 percent of the Data Center values. Presumably, the computed daily mean discharges are in this same general accuracy range. Inasmuch as the agreement between measured and computed hydrographs obtained during the calibration is good and the average relation for the variation of $\eta$ (fig. 7) is moderately well defined, it also seems reasonable to conclude that the computed instantaneous discharges are fairly accurate.

Continuous-flow hydrographs for the period of discharge record at Beaver exhibit the following characteristics:

1. For daily mean discharges of less than about 125,000 $\mathrm{ft}^{3} / \mathrm{s}\left(3,540 \mathrm{~m}^{3} / \mathrm{s}\right)$, flow reverses (flow upstream) during at least one of the flood periods during the day, and reversals are very common for both flood periods.

2. For daily mean discharges of about 125,000 to 185,000 $\mathrm{ft}^{3} / \mathrm{s}\left(3,540\right.$ to $\left.5,240 \mathrm{~m}^{3} / \mathrm{s}\right)$, flow almost always reverses during the strongest flood.

3. For daily mean discharges of about 185,000 to 225,000 $\mathrm{ft}^{3} / \mathrm{s}\left(5,240\right.$ to $\left.6,370 \mathrm{~m}^{3} / \mathrm{s}\right)$, the flow reverses occasionally during the strongest flood. 


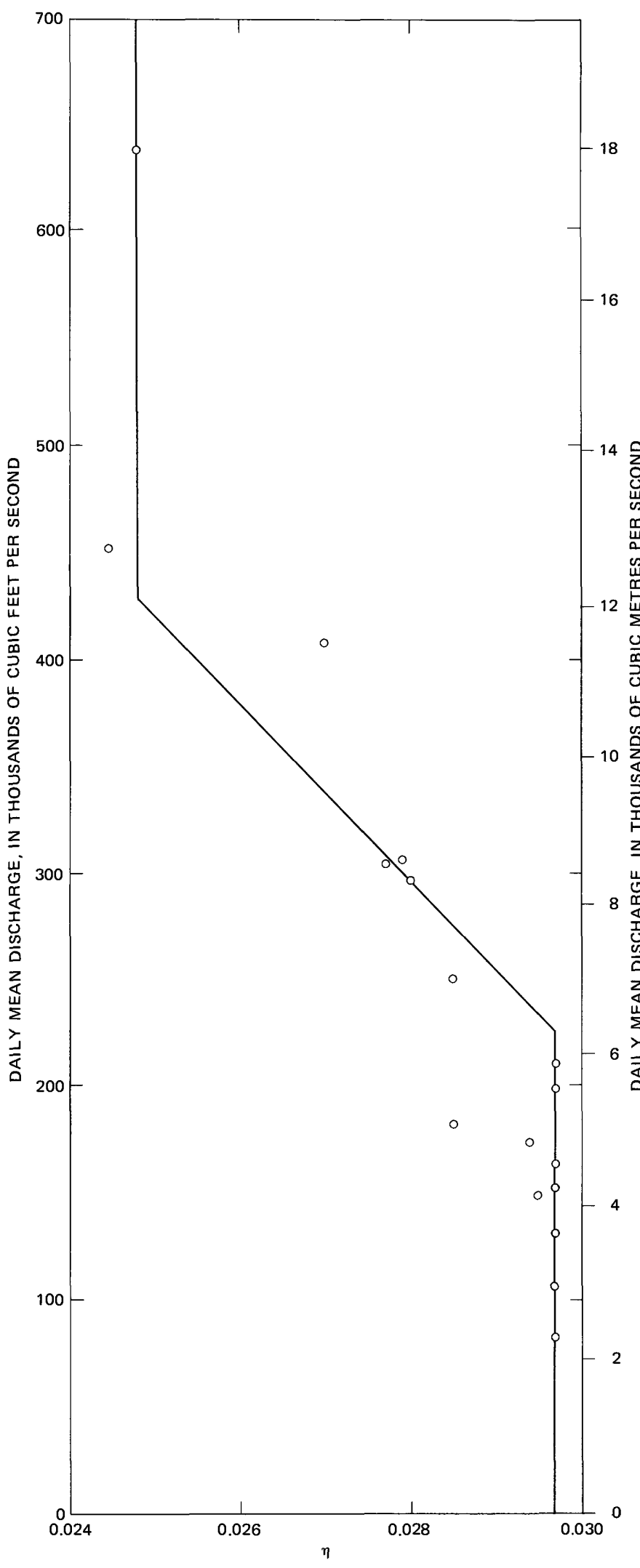

FIGURE 7, - Variation of the flow-resistance, coefficient, $\eta$, with daily mean discharge, Columbia Kiver at Beaver Army Terminal near Quncy, Oreg.
4. For daily mean discharges greater than about 225,000 $\mathrm{ft}^{3} / \mathrm{s}\left(6,370 \mathrm{~m}^{3} / \mathrm{s}\right)$, the flow rarely reverses.

A review of the daily mean discharges shows that, on the average, flow reversals occur during about 10 months of the year and at all times except during the period of high upland flow during the spring.

During the calibration, it was found that a gage correction of 0.01 foot $(0.3 \mathrm{~cm})$ would change the daily mean discharge by about $5,000 \mathrm{ft}^{3} / \mathrm{s}\left(142 \mathrm{~m}^{3} / \mathrm{s}\right)$ or about 2 percent of the average daily mean discharge of $225,000 \mathrm{ft}^{3} / \mathrm{s}$ $\left(6,370 \mathrm{~m}^{3} / \mathrm{s}\right)$ for the period of discharge record at Beaver. Although the stage records from both the float-stilling well system and the bubble gage are accurate at best to only \pm 0.01 foot, $(0.3 \mathrm{~cm})$, it is reasonable to assume that, on the average throughout a tidal cycle, the difference between gage readings would be in error no more than about 0.01 foot $(0.3 \mathrm{~cm})$.

\section{ASTORIA REACH}

The reach at Astoria extends from Tongue Point (CRM 17.5) downstream to the west side of Astoria (CRM 13.1), as shown in figure 1. The flow characteristics of the Astoria reach are complicated by both longitudinal and lateral salinity gradients that result from saltwater intrusion into the reach. Generally, salinity is present during at least one of the floodtides each day, and usually during both, except when runoff is high in the late spring. Also the geometry of the reach is complex (fig. 8); the navigational channel is along the south shore, the center part is laced diagonally with shallow minor channels and with flats that are exposed at low tide, and a deep channel along the north shore at the lower end of the reach divides and becomes shallow toward the upstream end of the reach. The width-tolength ratio of the reach is close to 1.0.

The upstream gage was located at the U.S. Coast Guard Tongue Point Station and consisted of a digital recorder coupled to a permanent tide-station gage recorder that is operated by the U.S. Coast and Geodetic Survey. The gage is float-stilling-well type and is maintained daily by Coast Guard personnel. The lower gage was installed on Pier 1 of the Port of Astoria Docks. This gage also was a float-stilling-well type with digital and graphic water-stage recorders. A-C synchronous motordriven timers were used to obtain virtually simultaneous stage readings at both gages every 15 minutes. The datum to which the gages were set was the same as for the Beaver reach; that is, "MSL 1929" -10 feet (3.048 $\mathrm{m})$. Channel cross-sectional geometry was defined from eight cross sections (fig. 8) equally spaced along the reach. The shape and dimensions of each section were determined from Coast and Geodetic Survey navigational charts rather than from field-survey measurements. Data from the eight sections were com- 


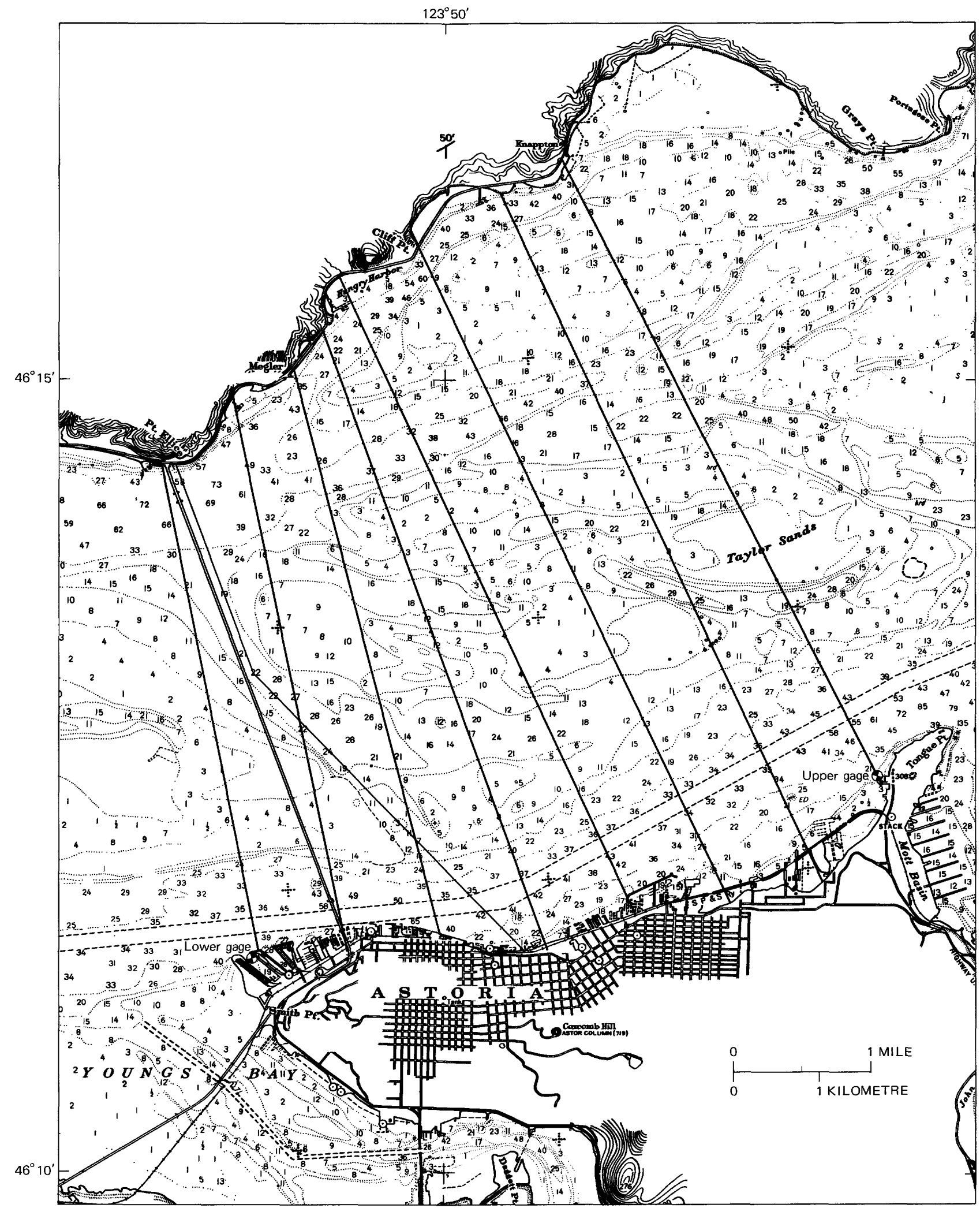

FIGURE 8 - Astoria reach showing crose sections where channel geometry was defined. Numbers within estuary boundaries indicate depths, in feet, at mean lower low water. Base from U.S. Coast and Goedetic Survey; Columbia River Chart 6151, Oregon-Washington, 1968. 
bined to define the geometric characteristics of cross sections that are representative of upper and lower subreaches which roughly divide the total reach in half (table 3 ). The length of the reach was obtained by measuring the distance between the two gages along the centerline of the navigational channel.

Discharge hydrographs for calibration of the mathematical model were obtained at the measuring cross section at Astoria (fig. 8) exclusively by the MOVD method. With this method, the complex velocity profiles produced by salinity gradients are defined throughout the entire depth; thus, regardless of conditions, accurate section discharges can be measured. As at Beaver, measurements were scheduled so that both ebb and flood discharges would be defined during the measurement sequence.

Discharge measurements at Astoria began on April 13, 1966, and were concluded on May 19, 1970. During this period, 20 discharge hydrographs, or a total of 82 lateral traverses, were made during varying flow conditions. A summary of the discharge measurements is given in table 4. At Astoria, it was considered a successful day if four or more complete traverses could be made. On the average, it would take about 2 hours for a complete round-trip lateral traverse. Of the 2 hours, about $1 \frac{1 / 2}{2}$

TABLE 3. - Areas and top widths of average cross sections representative of the two subreaches in the Astoria reach

\begin{tabular}{|c|c|c|c|c|c|}
\hline \multicolumn{3}{|c|}{ Upper Subreach } & \multicolumn{3}{|c|}{ Lower Subreach } \\
\hline$\underset{\text { (ft) }}{\text { Depth' }}$ & $\begin{array}{c}\text { Top } \\
\text { width } \\
\text { (ft) }\end{array}$ & $\begin{array}{l}\text { Cross- } \\
\text { sectional } \\
\text { area } \\
\text { (sq ft) }\end{array}$ & $\underset{\text { (ft) }}{\text { Depth' }}$ & $\begin{array}{c}\text { Top } \\
\text { width } \\
\text { (ft) }\end{array}$ & $\begin{array}{c}\text { Cross- } \\
\text { sectiona } \\
\text { area } \\
\text { (sq ft) }\end{array}$ \\
\hline $\begin{array}{r}0 \\
2.0 \\
4.0 \\
6.0 \\
7.0 \\
8.0 \\
24.0\end{array}$ & $\begin{array}{l}17,500 \\
19,700 \\
23,100 \\
24,300 \\
25,600 \\
27,200 \\
27,200\end{array}$ & $\begin{array}{l}226,000 \\
263,000 \\
306,000 \\
353,000 \\
378,000 \\
405,000 \\
840,000\end{array}$ & $\begin{array}{r}0 \\
2.0 \\
4.0 \\
6.0 \\
8.0 \\
24.0 \\
---\end{array}$ & $\begin{array}{l}16,900 \\
17,500 \\
19,700 \\
20,400 \\
21,900 \\
21,900 \\
- \\
-\end{array}$ & $\begin{array}{l}286,000 \\
321,000 \\
358,000 \\
398,000 \\
440,000 \\
791,000 \\
----\end{array}$ \\
\hline
\end{tabular}

'Depth of water above gage datum ("MSL 1929" $-10 \mathrm{ft}$ ).

TABLE 4. - Summary of discharge measurements at Astoria, Oreg.

\begin{tabular}{|c|c|c|c|c|c|}
\hline \multicolumn{3}{|c|}{ Date } & $\begin{array}{c}\text { Number of } \\
\text { lateral } \\
\text { traverses }\end{array}$ & $\begin{array}{c}\text { Period of } \\
\text { defined } \\
\text { hydrograph } \\
\text { (hours) }\end{array}$ & $\begin{array}{c}\text { Daily mean } \\
\text { discharge } \\
\text { at Astoria } \\
\left(\mathrm{ft}^{3 / \mathbf{s}}\right)\end{array}$ \\
\hline \multicolumn{6}{|l|}{1966} \\
\hline Apr. & 13 & -------- & 4 & 9.8 & 223,000 \\
\hline May & 25 & ------- & 2 & 5 & 331,000 \\
\hline July & 6 & - - - - - & 4 & 9.5 & 287,000 \\
\hline July & 28 & $-\cdots$ & 4 & 10.3 & 203,000 \\
\hline Nov. & 4 & -------- & 3 & 8.3 & 105,000 \\
\hline \multirow{3}{*}{\multicolumn{2}{|c|}{\begin{tabular}{l} 
July \\
Aug. \\
Sept. \\
\multicolumn{1968}{l}{}
\end{tabular}}} & -------- & 3 & 7 & 276,000 \\
\hline & & $-\cdots-\cdots$ & 4 & 8.8 & \\
\hline & & $----\cdots$ & 4 & 9.5 & 85,000 \\
\hline $\begin{array}{l}\text { Feb. } \\
\text { Apr. }\end{array}$ & 13 & -------- & 4 & 9.5 & 202,000 \\
\hline Apr. & $\begin{array}{r}3 \\
10\end{array}$ & -------0 & 3 & 6.5 & 236.000 \\
\hline June & 16 & 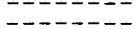 & $\begin{array}{l}5 \\
6\end{array}$ & $\begin{array}{l}11.5 \\
11.8\end{array}$ & 112,000 \\
\hline July & 26 & -----1 & $\begin{array}{l}0 \\
5\end{array}$ & $\begin{array}{l}11.0 \\
11.3\end{array}$ & 278,000 \\
\hline Sept. & 12 & ------- & 5 & 10.8 & 168,000 \\
\hline Oct. & 17 & ------ & 4 & 8.8 & 98,000 \\
\hline Dec. & 18 & -------- & 3 & 7.3 & 350,000 \\
\hline Apr. ${ }_{1970}$ & 24 & ------- & 5 & 10 & 442,000 \\
\hline Mar. & 7 & $-\cdots-\cdots$ & 5 & 8.3 & 268,000 \\
\hline Apr. & 13 & - - - - - & 5 & 10.3 & 188,000 \\
\hline May & 19 & ------- & 4 & 9.5 & 292,000 \\
\hline
\end{tabular}

hours were spent obtaining the measurements, and the other one-half hour was spent traveling back across the 4-mile-wide (6-km-wide) cross section. Lateral traverses were always started on the north side of the estuary so time differences between corresponding verticals of the different traverses would be the same.

Weather conditions played a very important part in how successful a measurement sequence would be. Heavy morning fogs caused delays in starting, and winds caused cancellations or delays in the starting time and early terminations of the measurements. Equipment malfunctions also caused late starts, early terminations, or delays during the discharge measurements.

\section{CALIBRATION PROCEDURE}

From the beginning of the study, there was speculation as to whether any one-demensional model could be adapted to provide reasonably accurate discharges throughout the tidal cycle at Astoria because of the complex geometry of the reach, the existence of salinity gradients, and the presence - at particular times in each tidal cycle - of diametrically opposed flow both within a vertical and laterally within the cross section. In order to provide the most flexibility, the model based on solution of the flow equations by the method of characteristics (Lai, 1967) was adopted and computations were made within the framework of a two-subreach system. The initial calibration procedure for the Astoria reach was the same as that used for the Beaver reach; that is, an attempt was made to determine values for the datum correction and flow resistance, $\eta$, by the trialand-error procedure. After evaluating many trials with various combinations of datum corrections and $\eta$ 's, it was concluded that (1) a constant datum correction could not be determined, and (2) use of $\eta=0.025$ produced flow hydrographs with maximum and minimum discharges that corresponded closely to comparable measured data, but whose shapes deviated consistently from measured hydrographs.

Baltzer and Lai (1968) showed, with data from Threemile Slough near Rio Vista, Calif., that $\eta$ increases sharply as the Reynolds number approaches zero. Because the Reynolds number is a function of and varies mainly with water velocity, in effect, they showed that as the velocity (or discharge) approaches zero, $\eta$ increases. Because the tidal pattern at Astoria is such that the discharge passes through zero four times each day, the variation of $\eta$ is a significant consideration. To ascertain how $\eta$ varies with time at Astoria, the model was solved for $\eta$ by using measured discharges and an arbitrary datum correction. Computed $\eta$ values, normalized by dividing by the minimum computed $\eta$ value, are plotted in figure 9 against the corresponding relative times, $T / \Delta T$, in the period between zero discharges. The graph in figure 9 for ebb periods shows that for relative times 


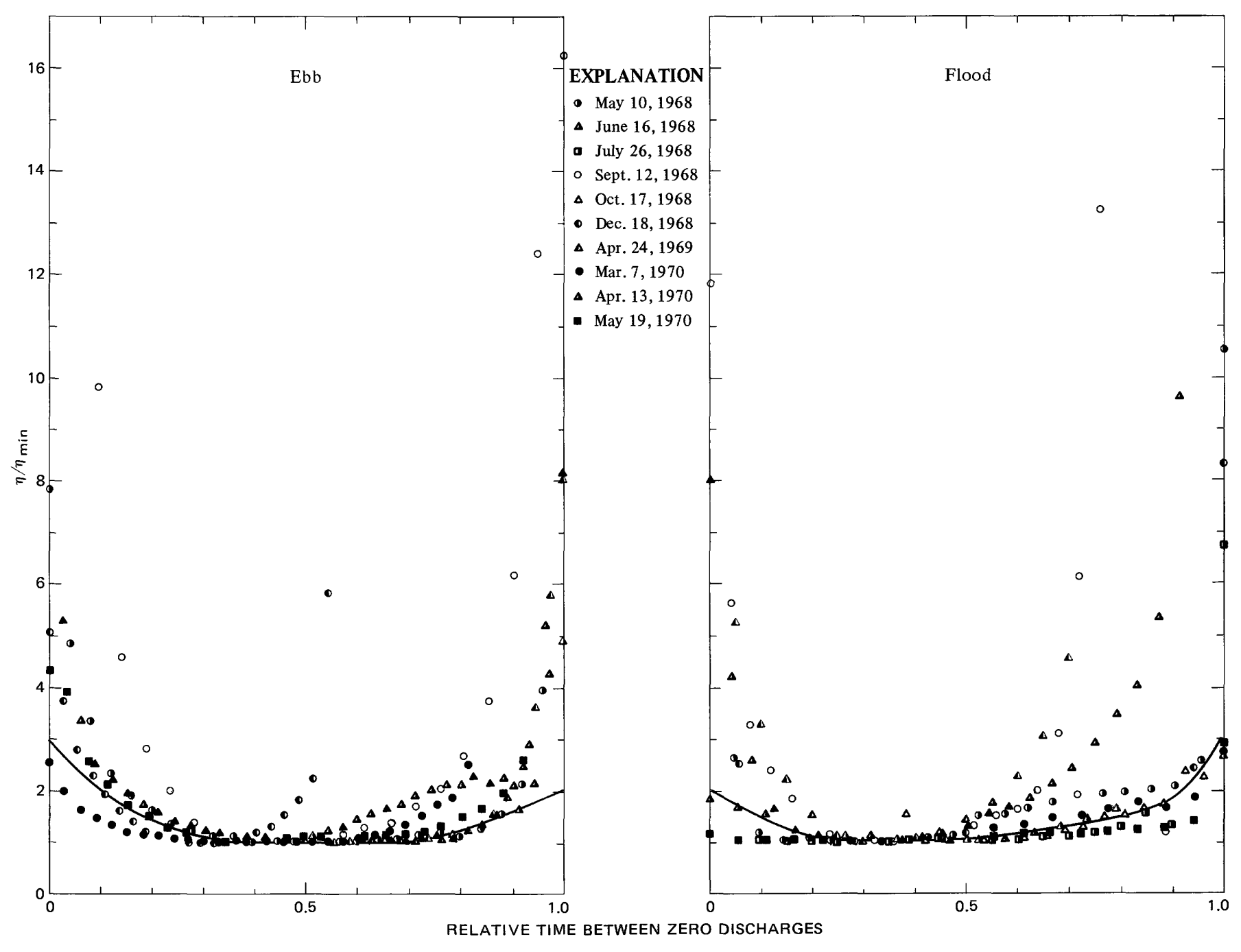

FIGURE 9. - Change in $\eta / \eta_{\min }$ with relative time at Astoria, Oreg.

between 0.35 and 0.70 , the value of $\eta$ is constant. For the remaining 65 percent of the time, $\eta$ increases as $T / \Delta T$ approaches zero and 1.0. For flood periods (fig. 9), $\eta$ is constant and a minimum for $T / \Delta T$ values between 0.23 and 0.47 or for 24 percent of the time. As with ebb periods, whenever $\eta$ is not at the minimum value it progressively increases as $T / \Delta T$ approaches zero and 1.0. It should be noted that the data in figure 9 cannot be taken as absolute because (1) the best datum correction for each hydrograph may not have been used in the computations; and (2) no deliberate provisions were taken to correct the model for salinity gradients, Coriolis effects, wind, and other factors that could have an effect on the discharge. However, the general trends in the figure can be assumed to be representative.

In order to incorporate the variation of $\eta$, the mathematical model was programmed to accept the curves shown in figure 9. With this change, close comparisons between measured and computed hydrographs (figs. 10,11 ) could be obtained by using $\eta_{\min }=0.025$, provided a different datum correction was used for each hydrograph. Apparently, the necessity for a variable datum correction is mainly a reflection of the fact that a variable water-surface slope (fall) correction is necessary to adjust the model to compensate for the influence of salinity gradients, complex geometry, and other factors not expressed in the fundamental equations.

Because a direct independent means for determining the required datum correction was not available, an indirect approach was adopted. First, a simple volumetric model to compute daily mean discharges at Astoria was developed. This model equated the daily mean discharge at Astoria with the algebraic sum of the daily mean discharge at Beaver and the daily rate of net change in the volume of storage within the reach between Beaver and Astoria. That is,

$$
\bar{Q}_{A}=\bar{Q}_{B}+\frac{\Delta V}{T}
$$




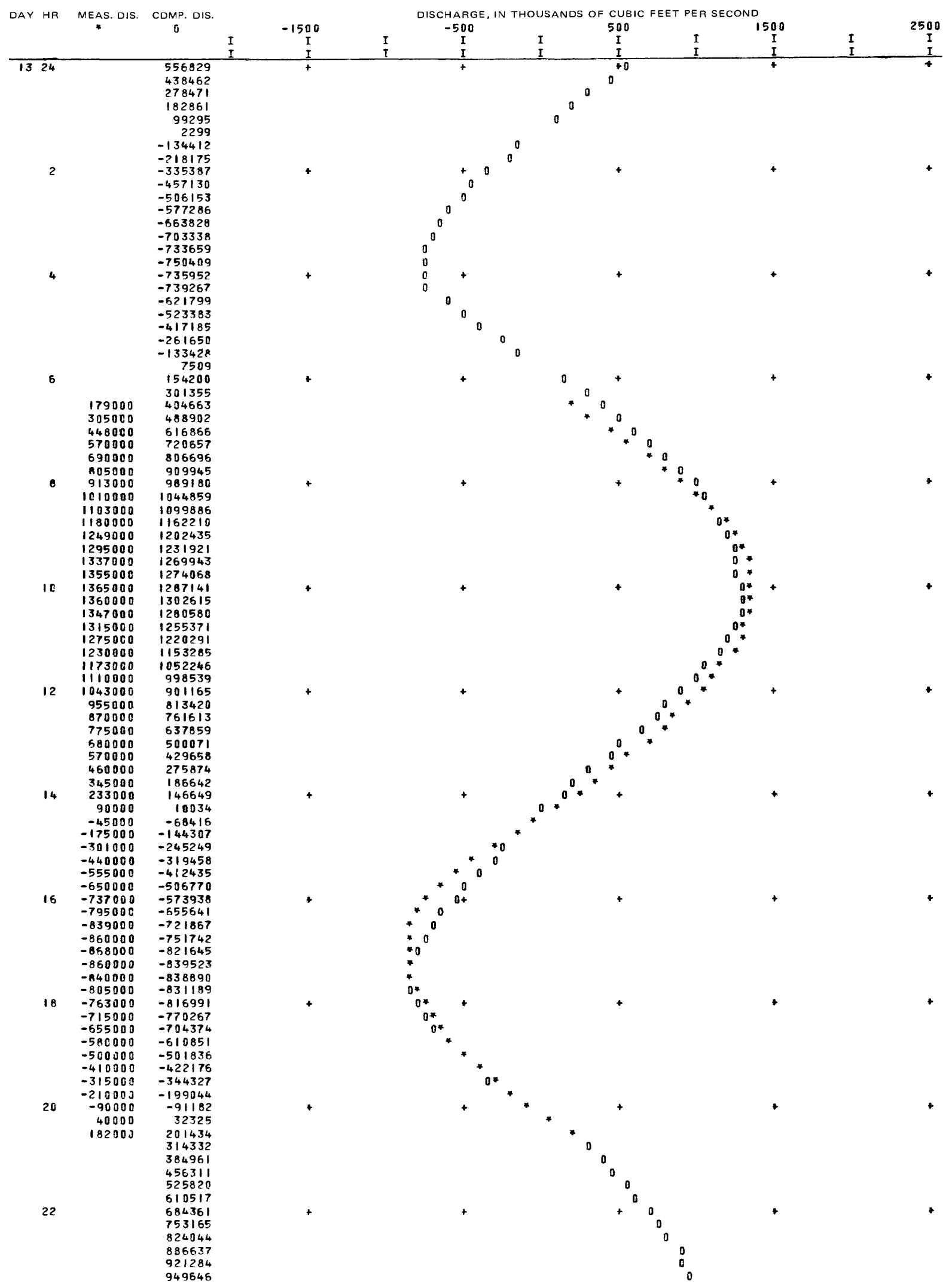

FIGURE 10. - Comparison between measured (*) and computed (0) discharges for low instantaneous discharges at Astoria, Oreg., on April 13, 1970. 


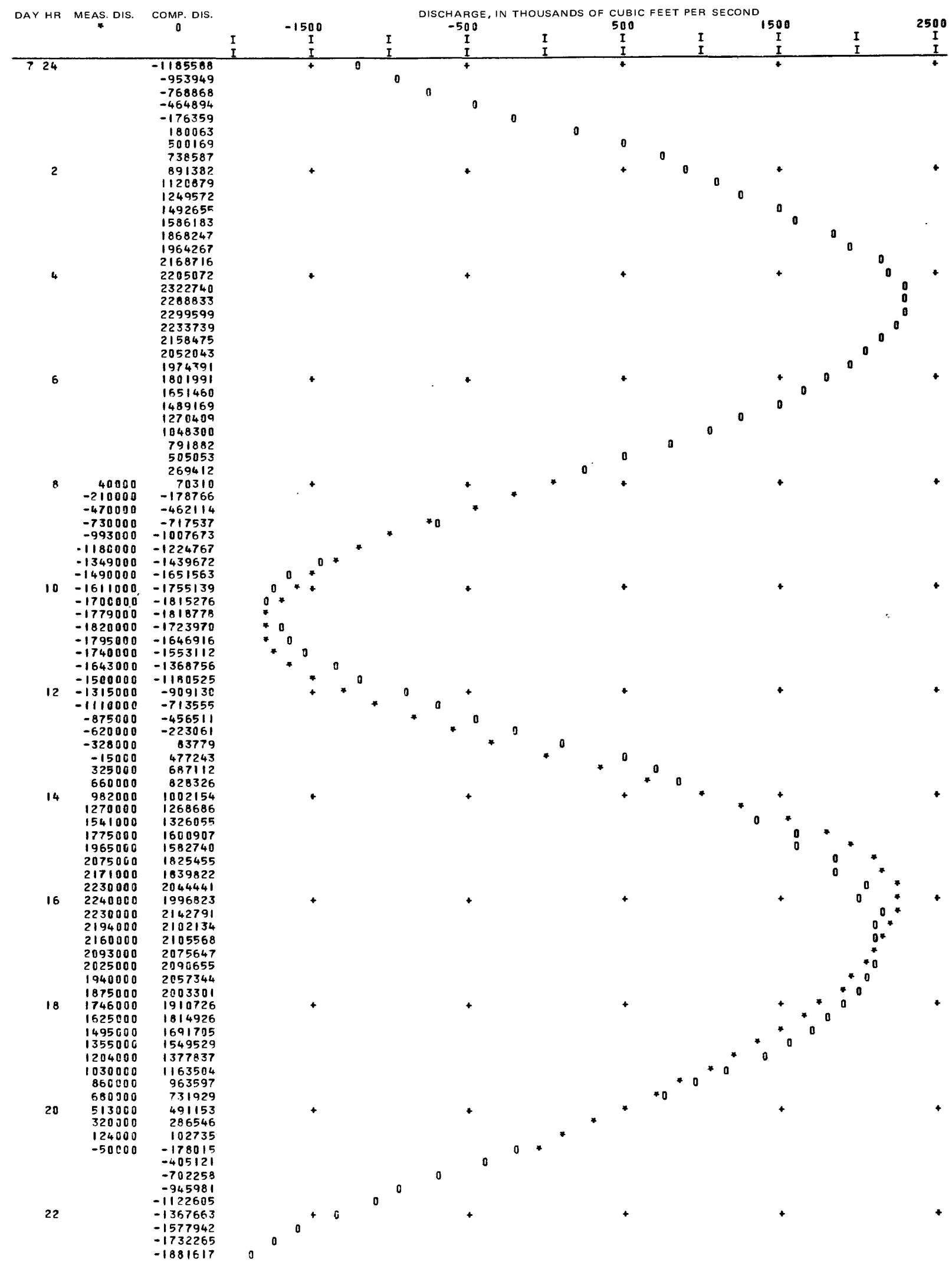

FIGURE 11. - Comparison between measured $\left(^{*}\right)$ and computed $(0)$ discharges for high instantaneous discharges at Astoria, Oreg., on March 7, 1970. 
where

$\bar{Q}_{A}$ and $\bar{Q}_{B}$ are the daily mean discharges, in cubic feet per second, at Astoria and Beaver, respectively;

$\Delta V$ is the difference in the volume of water within the reach, in cubic feet, at the beginning and at the end of each day; and

$T$ is 86,400 seconds (equivalent to 24 hours).

$\Delta V$ is the product of the surface area of the reach, $K^{\prime}$, and the weighted average depth of the net change in storage, $\Delta S^{\prime}$, which may be either positive or negative. $K^{\prime}$ was determined from a correlation with the stage at Tongue Point, $S_{T P}$, at the beginning of the day; the correlation was established with $K^{\prime}$ values obtained by solving equation 1 with values of $Q_{A}$ for days when discharge hydrographs were defined at Astoria, comparable values of $Q_{B}$ computed from the Beaver model, and values of $\Delta S^{\prime}$ determined from

$$
\Delta S^{\prime}=(2 / 3) \Delta S_{T P}+(1 / 2) \Delta S_{B},
$$

where

$\Delta S_{T P}$ and $\Delta S_{B}$ are the differences in stage between the beginning and end of each day at Tongue Point and at Beaver, respectively.

Equation 2 was determined to give $\Delta S^{\prime}$ values that, in turn, yielded $K^{\prime}$ values which gave the best correlation with the Tongue Point stages. The equation also roughly reflects the fact that approximately two-thirds of the surface area is located in the lower one-third of the reach.

Daily mean discharges at Astoria computed from equation 1 were used to calculate monthly mean discharges. These values were compared with monthly mean values computed by the Northwest Water Resources Data Center by a routing technique (Orem, 1968). Because the agreement between the monthly mean discharges was consistently within \pm 5 percent, the individual daily mean discharges were assumed to be reasonably accurate. Then, for each day, trial discharges were computed every 15 minutes with the mathematical model, using different daily datum corrections, until the resultant daily mean discharge corresponded within \pm 5 percent of the "known" daily mean discharge for each day determined from the volumetric model (eq 1).

\section{MATHEMATICAL-MODEL DISCHARGE RESULTS}

A continuous record of the discharge at Astoria every 15 minutes was computed by the trial procedure throughout the period from March 1, 1968, to June 30, 1970 , except during periods of missing gage records. A summary of this record (app. 1) shows that daily mean discharges ranged from 630,000 to $-7,400 \mathrm{ft}^{3} / \mathrm{s}(17,800$ to
$-210 \mathrm{~m}^{3} / \mathrm{s}$; minus sign indicates upstream flow). Instantaneous discharges frequently exceeded 2 million $\mathrm{ft}^{3} / \mathrm{s}$ $\left(0.06\right.$ million $\left.\mathrm{m}^{3} / \mathrm{s}\right)$ downstream and 1.5 million $\mathrm{ft}^{3} / \mathrm{s}(0.04$ million $\mathrm{m}^{3} / \mathrm{s}$ ) upstream (fig. 11). Near-surface velocities observed during the discharge measurements ranged up to $8 \mathrm{ft} / \mathrm{s}(2.4 \mathrm{~m} / \mathrm{s})$ during the ebb and were as high as 6 $\mathrm{ft} / \mathrm{s}(1.8 \mathrm{~m} / \mathrm{s})$ during the flood. However, the timeaverage velocity in the cross section is about $3 \mathrm{ft} / \mathrm{s}(0.9$ $\mathrm{m} / \mathrm{s})$ during an ebb and about $2 \mathrm{ft} / \mathrm{s}(0.6 \mathrm{~m} / \mathrm{s})$ during a flood.

Daily mean discharges determined from instantaneous discharges computed with the mathematical model (solution by the method of characteristics) are considered to be reasonably accurate because they were adjusted by trial to be within \pm 5 percent of the results obtained with the volumetric model. However, because the datum (slope) correction had to be applied as a daily factor and could not be varied throughout the tidal cycle, the computed instantaneous discharges are generally less accurate than the daily mean discharges. A statistical analysis of the percentage differences between discharges computed with the model and comparable discharges from the measured hydrographs is presented in appendix 2. The analysis indicates that the probability is 0.90 that 90 percent of all computed instantaneous discharges greater than $1,250,000 \mathrm{ft}^{3} / \mathrm{s}$ $\left(35,400 \mathrm{~m}^{3} / \mathrm{s}\right.$; both ebb or flood discharges) will be within about \pm 25 percent of the actual discharge; the error decreases as the discharge increases. (See fig. 18 and table 7.) For discharges less than $1,250,000 \mathrm{ft}^{3} / \mathrm{s}(35,400$ $\mathrm{m}^{3} / \mathrm{s}$ ), the percentage error increases rapidly as discharge decreases. Flows less than $1,250,000 \mathrm{ft}^{3} / \mathrm{s}\left(35,400 \mathrm{~m}^{3} / \mathrm{s}\right)$ generally occur only during those periods in the tidal cycle when discharge either is increasing or decreasing rapidly after having been zero. Hence, even though the proportion of time such flows occur may be fairly large, their contribution to the total volume of flow passing the cross section during an entire ebb or flood is generally small. For this reason, the large errors, as such, are not significant when the volume of flow during a partial tidal cycle is a prime concern.

During calibration of the Astoria reach, it was determined that the model was very sensitive to datum corrections. On the average, a correction of 0.01 foot $(0.3$ $\mathrm{cm}$ ) would change the daily mean discharge by about $25,000 \mathrm{ft}^{3} / \mathrm{s}\left(710 \mathrm{~m}^{3} / \mathrm{s}\right)$. This extreme sensitivity is believed to have resulted primarily because the reach was not long enough and the cross-sectional area was very large. Although the reach length was 4.4 miles (7.1 $\mathrm{km})$, the maximum water-surface fall was only slightly over 1.0 foot $(30 \mathrm{~cm})$, and the average fall was only about 0.65 foot $(20 \mathrm{~cm})$. Hence, a datum correction of 0.01 foot $(0.3 \mathrm{~cm})$ caused an appreciable change in the fall, and this caused a significant change in computed velocity that, in turn, was magnified into a large change in discharge because of the extensive size of the cross section. 


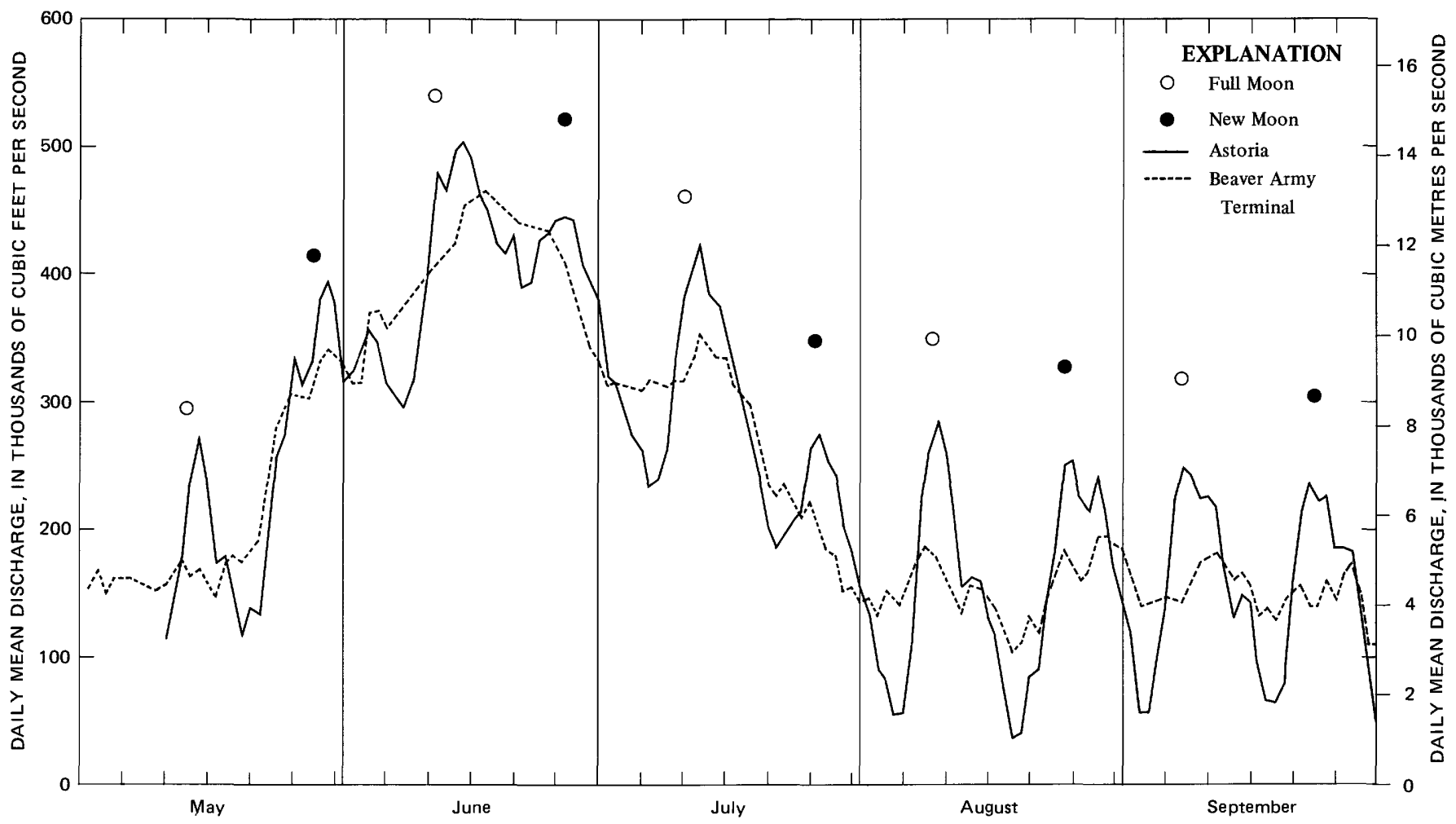

FIGURE 12. - Daily mean discharges at Beaver Army Terminal and Astoria, Oreg., May-September 1968

In tidal flow, the daily mean discharge is not necessarily indicative of the magnitude of upland flow as it is in nontidal flow. According to the volumetric model, and daily mean discharge at the station may be either less or greater than the upland discharge; the difference is caused by the net change in storage within the reach upstream from the station. The effect of changes in storage is shown in figure 12 by the hydrographs of the daily mean discharges at Beaver and Astoria. Although there is little inflow into the Columbia River between Beaver and Astoria, daily mean discharges fluctuate cyclically through a much greater range at Astoria than they do at Beaver because of the greater change in the amount of storage per unit change in stage at Astoria. The character of the cyclic pattern of the hydrograph for Astoria is affected significantly by the combined effects of (1) the daily 50-minute shift in the position of the tide curve relative to absolute clock time due to the difference in the length of lunar (24.8 hours) and solar (24 hours) days, and (2) the cyclic variation in maximum and minimum tide heights that occur with a frequency of about 14.3 days (spring tides occur a day or two after a full moon or a new moon, and neap tides occur about 7 days later). Essentially, the daily mean discharge increases from one day to the next, so long as $\Delta V$ (eq 1) increases or becomes less negative - that is, it increases so long as $\Delta S^{\prime}$ continues to increase algebraically. Daily mean discharges progressively decrease when the opposite trend in $\Delta S^{\prime}$ occurs. Because the moon is the major force-producing body that influences the timing and magnitude of the tides, moon phases correlate well with the cyclic variations in daily mean discharges. (See fig. 12.)

As stated earlier, the net change in storage during the day due to tide effects can be severe enough to produce daily mean discharges that are in the upstream direction at Astoria. For instance, on September 21-22, 1969, when the daily mean discharge at Beaver was about $100,000 \mathrm{ft}^{3} / \mathrm{s}\left(2,830 \mathrm{~m}^{3} / \mathrm{s}\right)$, the tides were such that the daily mean discharges at Astoria for these 2 days were 3,200 and $7,400 \mathrm{ft}^{3} / \mathrm{s}\left(91\right.$ and $\left.210 \mathrm{~m}^{3} / \mathrm{s}\right)$ upstream, respectively. At Beaver, similar cycling (but not net upstream daily flow) occurs; however, it appears that for daily mean discharges greater than about $450,000 \mathrm{ft}^{3} / \mathrm{s}$ $\left(12,700 \mathrm{~m}^{3} / \mathrm{s}\right)$, the cycling effect is essentially eliminated.

The cyclic variations in daily mean discharges significantly affect the degree to which the discharge during any short period of time (days) can be used to represent a longer term discharge. However, because the average period for the cyclic pattern is about 14 days, a monthly mean discharge will cover approximately 2 cycles and, therefore, should largely eliminate the effects of the ocean tides. 


\section{FLOW CHARACTERISTICS IN THE LOWER ESTUARY}

The adaptation and application of the onedimensional mathematical model for determining instantaneous discharges at Astoria was made possible by using, both implicitly and explicitly, information on flow and salinity distributions at the measuring cross section and elsewhere in the lower estuary. This same information also has been utilized to examine gross circulation and mixing patterns in the estuary.

\section{LATERAL CIRCULATION AT THE DISCHARGE-MEASURING CROSS SECTION, ASTORIA REACH}

To better understand the general pattern of flow in the estuary, the net circulation that results from differences in the lateral flow distribution of flood and ebb discharges was investigated at the measuring cross section at Astoria. Flow volumes from the dischargemeasurement sequences were used for this purpose.

For measured hydrographs in which both an ebb and flood period are defined, the quantities of water flowing upstream and downstream in the north and south channels ${ }^{1}$ were determined from the individual hydrographs for each part of the cross section (p. P5) that had been used to obtain the total flow hydrograph. The percentage of the total ebb volume that passed through each channel was then determined; a similar computation was made for the flood volumes. The various percentages are presented in table 5 .

The results in table 5 reveal some interesting facts about the flow characteristics and lateral circulation patterns at the measuring cross section. On the average, the north channel conveys 76 percent of the floodflow and 69 percent of the ebbflow, or 73 percent of the total flow. More importantly, however, comparison of the differences in the percentages of flow through each channel during the ebbs and floods indicates the net lateral circulation during the half tidal cycle defined by the hydrograph. For instance, on September 15, 1967 (table 5 ), the proportion of the ebbflow which passed through the north channel was 9 percent less than the proportion which passed through during the floodflow (9 percent loss). Conversely, the proportion in the south chanel was 9 percent greater. This indicates a net clockwise circulation wherein some of the floodwater that flowed into the estuary via the north channel returned to the ocean via the south channel. On October 17, 1968, the data indicated a net counterclockwise circulation. Examination of table 5 shows that the lateral circulation of water cor-

\footnotetext{
'In this analysis, the part of the estuary that includes the shallow midestuary area and the northernmost channel (fig. 8) is referred to as the north channel, and the navigational channel is called the south channel.
}

TABLE 5. - Lateral distribution of ebb and flood discharge in the measuring cross section at Astoria, CRM 14

[Flow period: E, ebb; $F$, flood]

\begin{tabular}{|c|c|c|c|c|c|c|}
\hline \multirow[t]{2}{*}{ Date } & \multirow{2}{*}{$\begin{array}{c}\text { Daily } \\
\text { mean } \\
\text { discharge } \\
\text { at Beaver } \\
\left(\mathrm{ft}^{\mathrm{t}} / \mathrm{s}\right)\end{array}$} & \multirow{2}{*}{$\begin{array}{c}\text { Flow } \\
\text { period }\end{array}$} & \multicolumn{2}{|c|}{ Percent of flow } & \multicolumn{2}{|c|}{$\begin{array}{l}\text { Difference in per- } \\
\text { centage of flow } \\
\text { conveyed during } \\
\text { ebb and flood }\end{array}$} \\
\hline & & & $\begin{array}{c}\text { North } \\
\text { channel }\end{array}$ & $\begin{array}{c}\text { South } \\
\text { channel }\end{array}$ & $\begin{array}{c}\text { North } \\
\text { channel }\end{array}$ & $\begin{array}{c}\text { South } \\
\text { channel }\end{array}$ \\
\hline $9-15-67$ & ' 129,000 & {$\left[\frac{F}{E}\right.$} & $\begin{array}{l}79 \\
70\end{array}$ & $\left.\begin{array}{l}21 \\
30\end{array}\right]$ & -9 & +9 \\
\hline $5-10-68$ & 157,000 & {$\left[\begin{array}{l}\mathrm{F} \\
\mathrm{E}\end{array}\right.$} & $\begin{array}{l}79 \\
72\end{array}$ & $\left.\begin{array}{l}21 \\
28\end{array}\right]$ & -7 & +7 \\
\hline 9- $\quad-59^{2}$ & $' 162,000$ & {$\left[\begin{array}{l}\mathrm{F} \\
\mathrm{E}\end{array}\right.$} & $\begin{array}{l}273 \\
{ }^{2} 68\end{array}$ & $\left.\begin{array}{l}227 \\
{ }^{2} 32\end{array}\right]$ & -5 & +5 \\
\hline $10-17-68$ & 166,000 & {$\left[\frac{\mathrm{F}}{\mathrm{E}}\right.$} & $\begin{array}{l}68 \\
80\end{array}$ & $\left.\begin{array}{l}32 \\
20\end{array}\right]$ & +12 & -12 \\
\hline $9-12-68$ & 171,000 & {$\left[\begin{array}{c}\mathrm{E} \\
\mathrm{F}\end{array}\right.$} & $\begin{array}{l}79 \\
70\end{array}$ & $\left.\begin{array}{l}21 \\
30\end{array}\right]$ & +9 & -9 \\
\hline $8-17-67$ & ${ }^{1} 175,000$ & {$\left[\begin{array}{l}\mathrm{F} \\
\mathrm{E}\end{array}\right.$} & $\begin{array}{l}71 \\
71\end{array}$ & $\left.\begin{array}{l}29 \\
29\end{array}\right]$ & 0 & 0 \\
\hline $3-7-70$ & 186,000 & {$\left[\begin{array}{l}\mathrm{F} \\
\mathrm{E}\end{array}\right.$} & $\begin{array}{l}73 \\
75\end{array}$ & $\left.\begin{array}{l}27 \\
25\end{array}\right]$ & +2 & -2 \\
\hline $4-13-70$ & 197,000 & {$\left[\begin{array}{l}\mathrm{E} \\
\mathrm{F}\end{array}\right.$} & $\begin{array}{l}58 \\
73\end{array}$ & $\left.\begin{array}{l}42 \\
27\end{array}\right]$ & -15 & +15 \\
\hline $12-18-68$ & 282,000 & {$\left[\begin{array}{l}\mathrm{F} \\
\mathrm{E}\end{array}\right.$} & $\begin{array}{l}80 \\
74\end{array}$ & $\begin{array}{l}{ }_{26}^{20} \\
\end{array}$ & -6 & +6 \\
\hline $5-19-70$ & 325,000 & {$\left[\frac{\mathrm{F}}{\mathrm{E}}\right.$} & $\begin{array}{l}79 \\
66\end{array}$ & $\left.\begin{array}{l}21 \\
34\end{array}\right]$ & -13 & +13 \\
\hline 4-24-69 & 415,000 & {$[\underset{F}{E}$} & $\begin{array}{l}58 \\
88\end{array}$ & $\left.\begin{array}{l}42 \\
12\end{array}\right]$ & -30 & +30 \\
\hline $6-16-68$ & 462,000 & {$\left[\begin{array}{l}\mathrm{E} \\
\mathrm{F}\end{array}\right.$} & $\begin{array}{r}65 \\
81\end{array}$ & $\left.\begin{array}{l}35 \\
19\end{array}\right]$ & -16 & +16 \\
\hline $6-\quad-59^{2}$ & 3551,000 & {$[\mathrm{~F}$} & $\begin{array}{l}{ }^{2} 77 \\
{ }^{2} 61\end{array}$ & $\left.\begin{array}{l}{ }^{2} 23 \\
{ }^{2} 39\end{array}\right]$ & -16 & +16 \\
\hline
\end{tabular}

'Daily mean discharge at Prescott, Oreg.
${ }^{2}$ From data presented by Hansen (1965).

'From data presented by Hansen (1965).
'Daily mean discharge at the mouth as computed by the U.S. Army Corps of Engineers (1960).

relates with the discharge at Beaver. For discharges at Beaver of less than about $165,000 \mathrm{ft}^{3} / \mathrm{s}\left(4,670 \mathrm{~m}^{3} / \mathrm{s}\right)$, the south channel conveys a proportionately higher flow during the ebb than the flood (gains water from the north channel during the ebbflow). For discharges from about 165,000 to $190,000 \mathrm{ft}^{3} / \mathrm{s}\left(4,670\right.$ to $\left.5,380 \mathrm{~m}^{3} / \mathrm{s}\right)$, the north channel gains water from the south channel during the ebbflow, and for discharges at Beaver greater than about $190,000 \mathrm{ft}^{3} / \mathrm{s}\left(5,380 \mathrm{~m}^{3} / \mathrm{s}\right)$, the south channel gains water from the north channel during the ebbflow.

Also shown in table 5 are percentages computed from Hansen's (1965, fig. 3, p. 954) interpretation of U.S. Army Corps of Engineers data collected at CRM 5.5 in June and September of 1959. The results from Hansen's work consistently agree with data from the measured hydrographs at the Astoria measuring cross section.

\section{FLOW-PREDOMINANCE PATTERNS AT THE DISCHARGE-MEASURING CROSS SECTION, ASTORIA REACH}

One especially useful way to characterize in simple terms the distribution of tidal flow in an estuary is by the method of flow predominance (Simmons, 1955). Application of this method to the analysis of velocity profile data from the measurement cross section at Astoria has provided an insight into the variation of the net vertical distribution of flow at various lateral locations across the section. 
TABLE 6. - Variation of flow predominance with depth at selected locations in the measuring cross section at Astoria, CRM 14

[Fraction of tidal cycle: A, half tidal cycle consisting of one flood and one ebb; B, full tidal cycle]

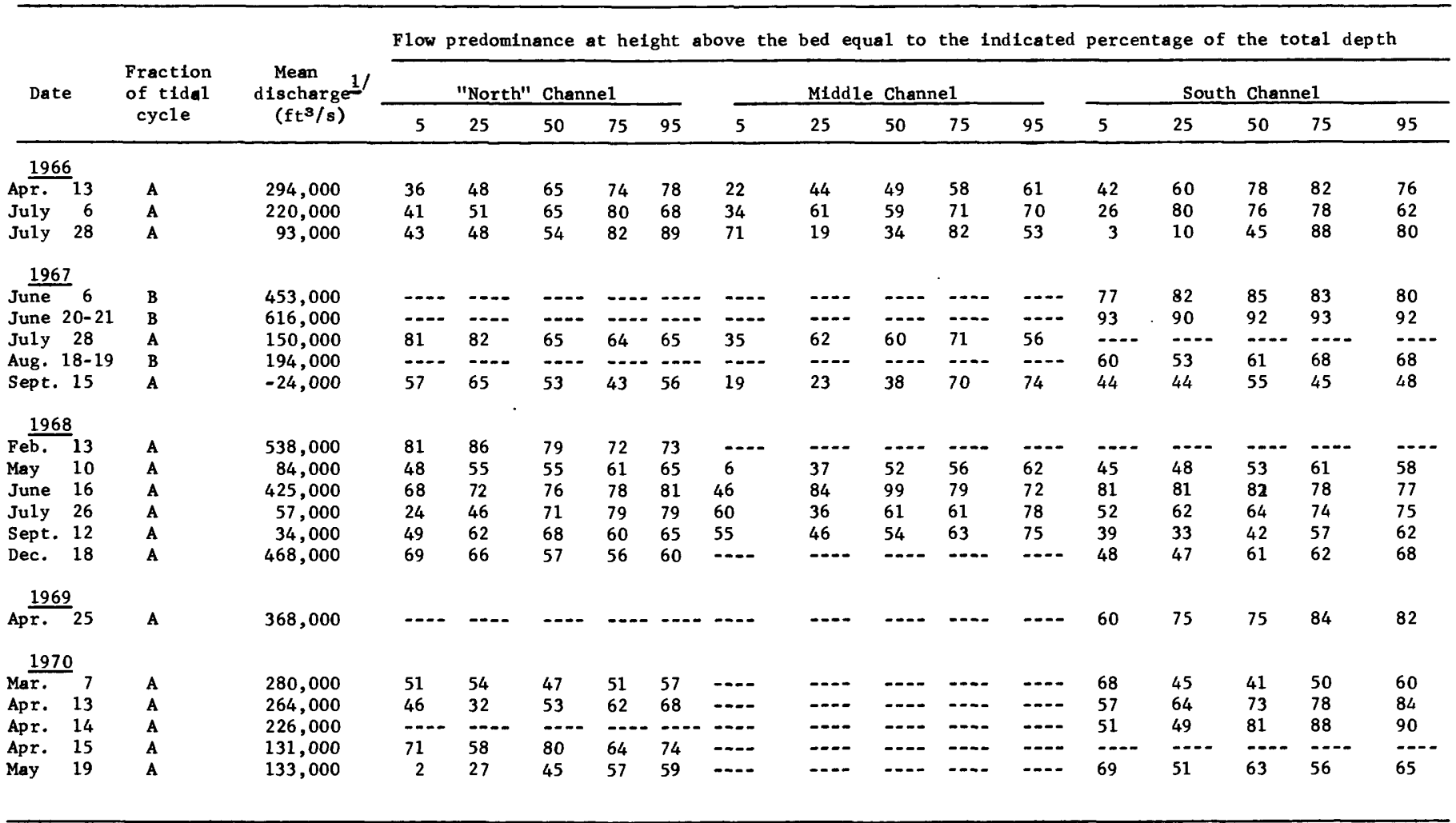

1/ Algebraic mean during the Indicated fraction of tidal cycle.

Flow predominance at a point is determined by the following procedure: (1) A conventional plot of the velocity normal to the cross section versus time is made over a complete tidal cycle; (2) the areas, $F$, subtended by the flood curves, and the areas, $E$, subtended by the ebb curves of the plot are planimetered; and (3) the flow predominance is calculated from

$$
\text { flow predominance }=\frac{\Sigma E}{\Sigma E+\Sigma F} \times 100 .
$$

Thus, flow predominance is the percentage of the total flow at a point that is downstream or toward the ocean. By having velocity data for several points in a vertical, a plot to define the distribution of flow predominance from surface to bottom at the vertical can be made. It is emphasized that this plot does not represent the distribution of discharge from surface to bottom, but only defines the direction and degree of predominance of flow throughout the vertical. For example, although a vertical may have a flow predominance of 50 percent at points near both the top and bottom, this does not mean that the same volume of water flowed past both points, because the top would probably have higher velocities than the bottom.
At the measurement cross section at Astoria, flow is conveyed through three broad parts termed "channels." Flow in the "north" and south channels parallels the banks, but flow in the middle channel is in a diagonal direction. In each of these channels, a specific vertical was selected to characterize the flow of the entire channel. For each discharge-measurement sequence (table 4) that had sufficient velocity data, flow predominance was calculated at heights above the bed of $5,25,50,75$, and 95 percent of the total depth at the selected vertical in each of the three channels. These data are given in table 6 . Inasmuch as the discharge measurement sequences were usually about 10 hours long, most of the flowpredominance values in table 6 are based on velocity data from only one-half of a tidal cycle instead of a complete tidal cycle. However, unless there were extreme differences between the high-high and the low-high, or the low-low and the high-low tides, flow-predominance values calculated using data for only one-half of a tidal cycle should be reasonably representative of the flowpredominance values for the complete tidal cycle. Also, the "mean discharge" given for each date in table 6 is the algebraic mean for exactly the same part of the tidal cy-

'In this analysis, the northernmost channel, the midestuary area, and the navigational channel are called the "north," middle, and south channels, respectively. 


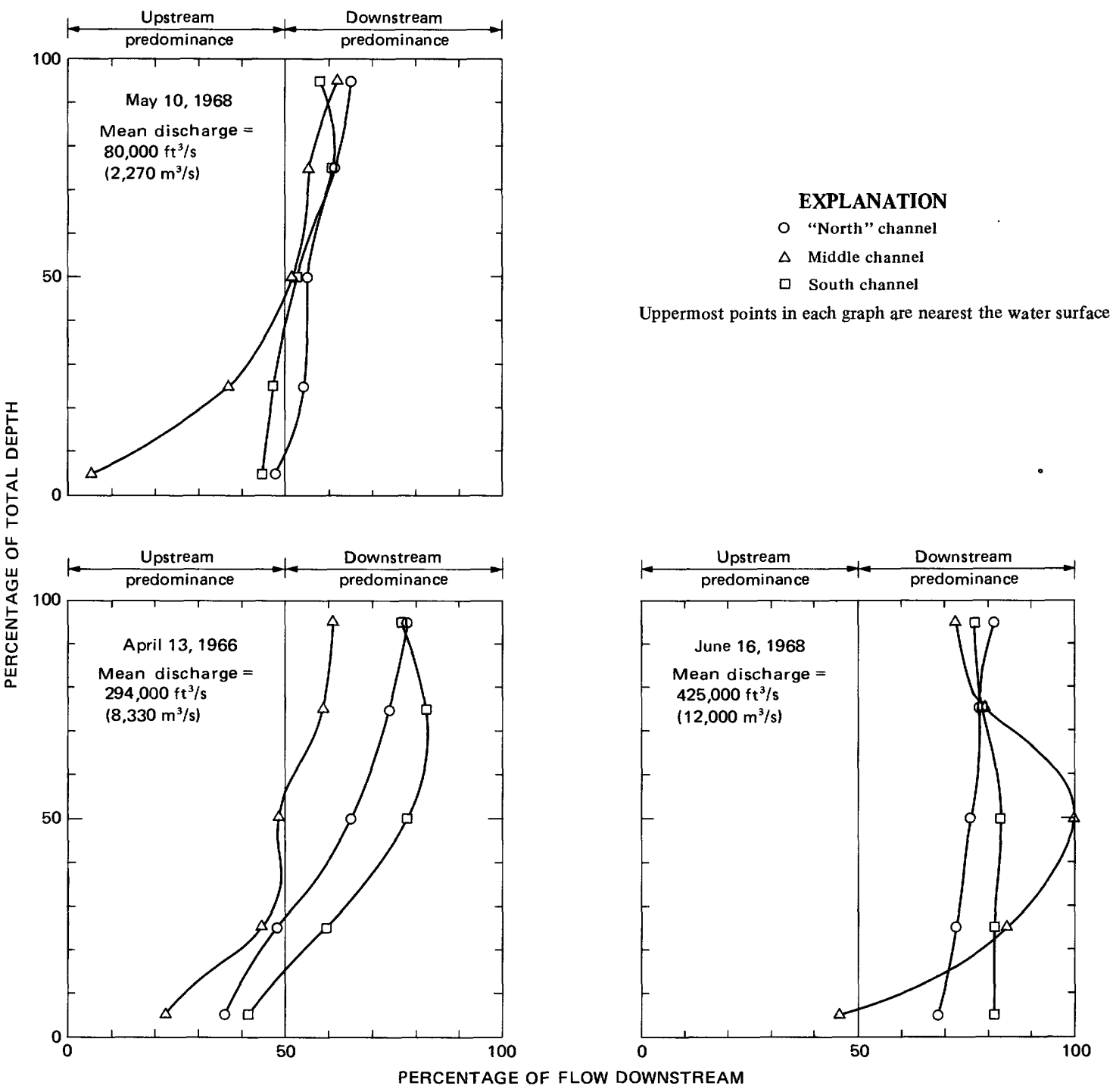

FigURE 13. - Vertical distribution of flow predominance in the "north," middle, and south channels at the measuring cross section at Astoria, CRM 14, for various mean discharges.

cle as was used to calculate the flow predominance. Therefore, the correlation between the two variables should be roughly the same as would be obtained from using-data for a full tidal cycle.

Flow-predominance curves for three different times are plotted in figure 13 to indicate how the flow distribution varies with the mean discharge at these verticals and within each channel. For zero upland discharge, normally the flow predominance at all depths would be close to 50 percent because there would be no possibility of stratification. The figure demonstrates that for some mean discharges the flow is predominantly upstream near the bottom and predominantly downstream near the surface.

The variation of flow predominance with mean discharge is shown more clearly in figure 14. In the "north" channel, at the bottom, flow is predominantly landward for all mean discharges of less than about $340,000 \mathrm{ft}^{3} / \mathrm{s}$ $\left(9,630 \mathrm{~m}^{3} / \mathrm{s}\right)$ and is most predominantly landward $(37$ percent seaward) at a mean discharge of $200,000 \mathrm{ft}^{3} / \mathrm{s}$ $\left(5,660 \mathrm{~m}^{3} / \mathrm{s}\right)$; as mean discharge increases, flow predominance gradually changes from landward to seaward and at $550,000 \mathrm{ft}^{3} / \mathrm{s}\left(15,600 \mathrm{~m}^{3} / \mathrm{s}\right)$ it reaches a value of 75 percent seaward. At the 25 percent depth, flow predominance remains at 50 percent for mean discharges of less than about $370,000 \mathrm{ft}^{3} / \mathrm{s}\left(10,500 \mathrm{~m}^{3} / \mathrm{s}\right)$ and increases gradually as mean discharge increases up to a value of 77 percent seaward at about $550,000 \mathrm{ft}^{3} / \mathrm{s}(15,600$ $\mathrm{m}^{3} / \mathrm{s}$ ). In the upper half of the vertical, seaward flow predominance increases rapidly to a value of 70 percent as the flow increases to a mean discharge of $100,000 \mathrm{ft}^{3} / \mathrm{s}$ $\left(2,830 \mathrm{~m}^{3} / \mathrm{s}\right)$. It then levels off and gradually increases to 78 percent at $550,000 \mathrm{ft}^{3} / \mathrm{s}\left(15,600 \mathrm{~m}^{3} / \mathrm{s}\right)$. For all depths within the vertical, flow predominance approached the 

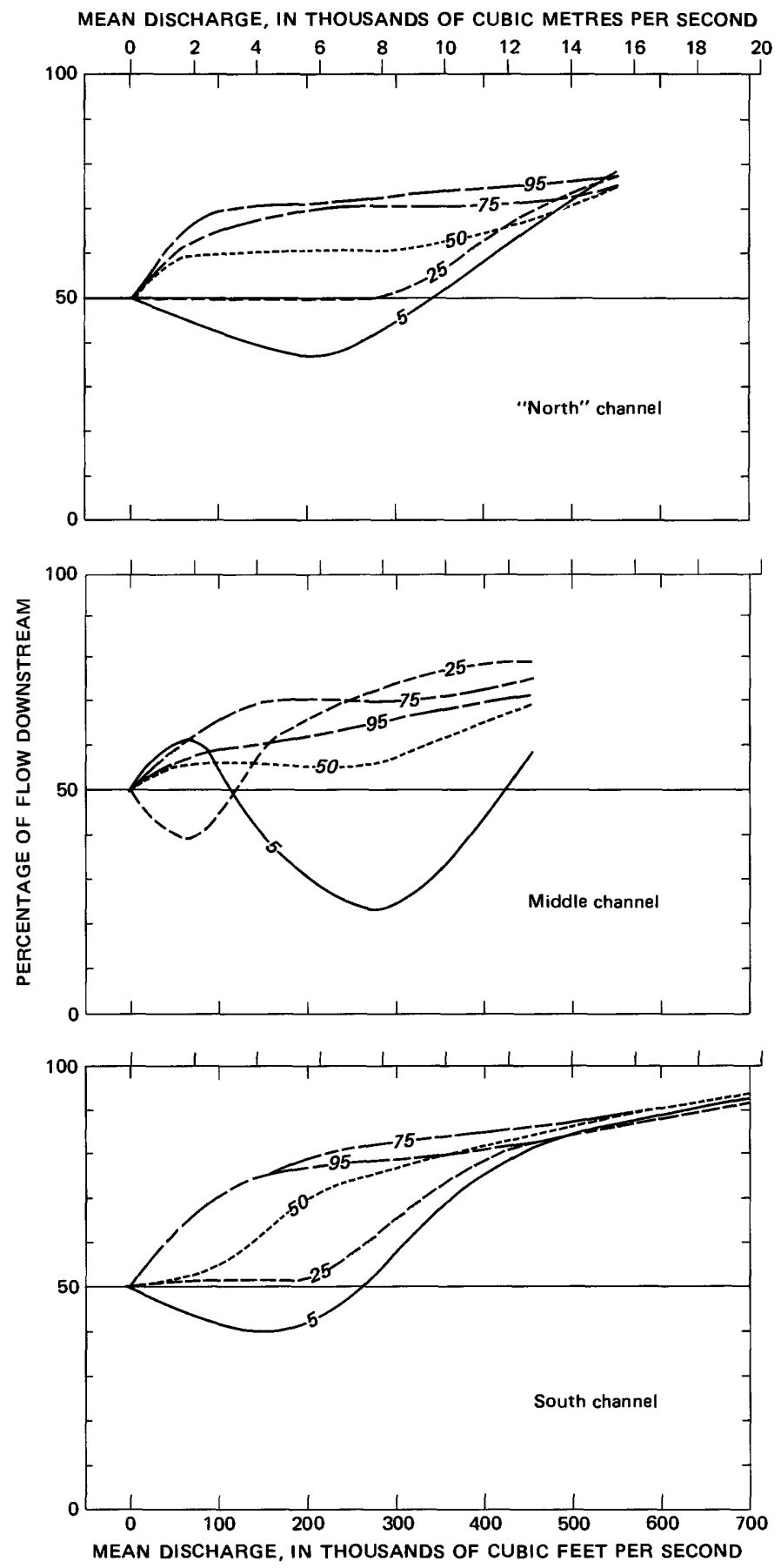

FIGURE 14. - Variation of flow predominance with mean discharge at the measuring cross section at Astoria, CRM 14. Numbers indicate height above bed expressed as a percentage of the total depth.

same level of about 77 percent at $550,000 \mathrm{ft}^{3} / \mathrm{s}(15,600$ $\mathrm{m}^{3} / \mathrm{s}$ ), but at no time during the measurement did the flow ever reach 100 percent seaward.

The flow-predominance pattern for the south channel is very similar to that for the "north" channel. Near the bottom it is less than 50 percent for low mean discharges and decreases to a minimum of 40 percent at a mean discharge of $150,000 \mathrm{ft}^{3} / \mathrm{s}\left(4,250 \mathrm{~m}^{3} / \mathrm{s}\right)$. With mean discharges greater than $150,000 \mathrm{ft}^{3} / \mathrm{s}\left(4,250 \mathrm{~m}^{3} / \mathrm{s}\right)$, it progres- sively increases to 50 percent at a mean discharge of $260,000 \mathrm{ft}^{3} / \mathrm{s}\left(7,360 \mathrm{~m}^{3} / \mathrm{s}\right)$ and is as high as 93 percent at a mean discharge of $700,000 \mathrm{ft}^{3} / \mathrm{s}\left(19,800 \mathrm{~m}^{3} / \mathrm{s}\right)$. At the 25 percent depth, flow predominance is close to 50 percent for mean discharges under $200,000 \mathrm{ft}^{3} / \mathrm{s}\left(5,660 \mathrm{~m}^{3} / \mathrm{s}\right)$, and increases as mean discharge increases to 92 percent at $700,000 \mathrm{ft}^{3} / \mathrm{s}\left(19,800 \mathrm{~m}^{3} / \mathrm{s}\right)$. In the upper half of the vertical, flow predominance increases rapidly with increases in mean discharge up to about $200,000 \mathrm{ft}^{3} / \mathrm{s}\left(5,660 \mathrm{~m}^{3} / \mathrm{s}\right)$ and then it gradually increases to 93 percent at 700,000 $\mathrm{ft}^{3} / \mathrm{s}\left(19,800 \mathrm{~m}^{3} / \mathrm{s}\right)$. Although flow predominance in the south channel was not defined at mean discharges greater than about $700,000 \mathrm{ft}^{3} / \mathrm{s}\left(19,800 \mathrm{~m}^{3} / \mathrm{s}\right)$, by extrapolation it appears that for a mean discharge of about 1 million $\mathrm{ft}^{3} / \mathrm{s}\left(0.03\right.$ million $\left.\mathrm{m}^{3} / \mathrm{s}\right)$ the flow at CRM 14 would be 100 percent seaward. This agrees with the mean discharge predicted for 100 percent seaward flow for the "north" channel.

Flow-predominance patterns for the middle channel are different from those in the "north" and south channels. At the bottom, flow predominance is seaward with mean discharges of less than $115,000 \mathrm{ft}^{3} / \mathrm{s}\left(3,260 \mathrm{~m}^{3} / \mathrm{s}\right)$; however, it is landward with mean discharges from 115,000 to $425,000 \mathrm{ft}^{3} / \mathrm{s}\left(3,260\right.$ to $\left.12,000 \mathrm{~m}^{3} / \mathrm{s}\right)$. At 25 percent of depth, flow predominance is landward with mean discharges of less than $120,000 \mathrm{ft}^{3} / \mathrm{s}\left(3,400 \mathrm{~m}^{3} / \mathrm{s}\right)$, but it is seaward at higher mean discharges. The upper half of the vertical follows the same pattern as was observed in the "north" and south channels except the magnitude of the seaward predominance is not as large. The main reason for the difference in flow patterns between the middle channel and the "north" and south channels is that the flow in the "north" and south channels is generally perpendicular to the cross section, whereas the flow in the middle channel is not and at times parallels the cross section.

\section{FLOW-PREDOMINANCE PATTERNS IN THE SOUTH CHANNEL, CRM 5.6-22.5}

For a more complete understanding of flow patterns in the estuary, data were collected at two different flow conditions to define sediment transport and flow characteristics along the longitudinal axis of the south channel. During a 3-day period when the tidal patterns and upland discharges were relatively constant, data were collected at seven stations that were located about 2 miles $(3.2 \mathrm{~km})$ apart. On each day, measurements were made at three adjacent stations from a single vessel that repetitively occupied each station about every 2 hours during the daylight hours. On the second day the occupied stations were located in the middle part of the study reach and the upstream and downstream stations corresponded, respectively, to the downstream station on the first day and the upstream station on the last day. Measurement data were combined according to the 

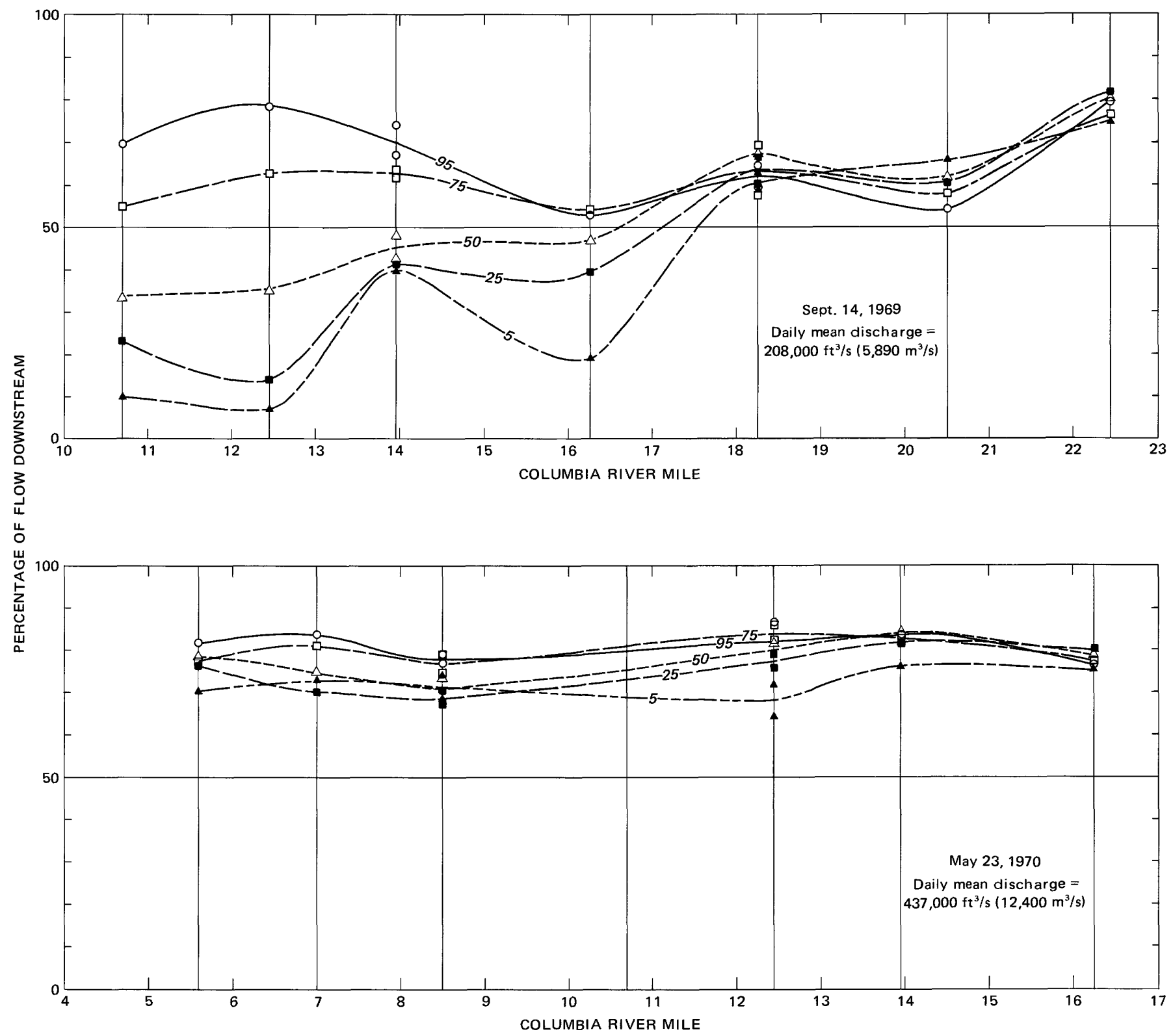

FIGURE 15. - Flow predominance along the longitudinal axis of the south channel during a half tidal cycle. Numbers indicate height above the bed expressed as a percentage of the total depth.

relative time of collection in the tidal cycle to give distribution curves that show the time variations of variables at all stations on the second (middle) day.

For the first flow condition (September 14, 1969) the daily mean discharge at the Astoria cross section was $208,000 \mathrm{ft}^{3} / \mathrm{s}\left(5,890 \mathrm{~m}^{3} / \mathrm{s}\right)$ and the study reach extended from CRM 10.7 to CRM 22.5. From velocity profile data, flow-predominance values were calculated for the seven stations at heights above the bed of $5,25,50,75$, and 95 percent of the total depth. A plot of these data (fig. 15) shows that upstream from CRM 17.5, the flow was predominantly downstream at all depths. Near the bottom, net flow was zero at CRM 17.5 and was predominantly upstream in the lower half of the study reach. At middepth, the net flow was zero at CRM 16.6 and downstream from that point it was predominantly landward. Flow in the upper layers remained predominantly downstream throughout the entire study reach.

For the second flow condition (May 23, 1970) the daily mean discharge at the Astoria cross section was 437,000 $\mathrm{ft}^{3} / \mathrm{s}\left(12,400 \mathrm{~m}^{3} / \mathrm{s}\right)$, and the study reach extended from CRM 5.6 to CRM 16.2. Velocity profiles collected at each of the 7 stations during this study also were used to compute flow predominance at heights above the bed of 5 , $25,50,75$, and 95 percent of the total depth. Figure 15 also shows these data. Near the bottom, the flow predominance ranged from 76 percent at the upstream 

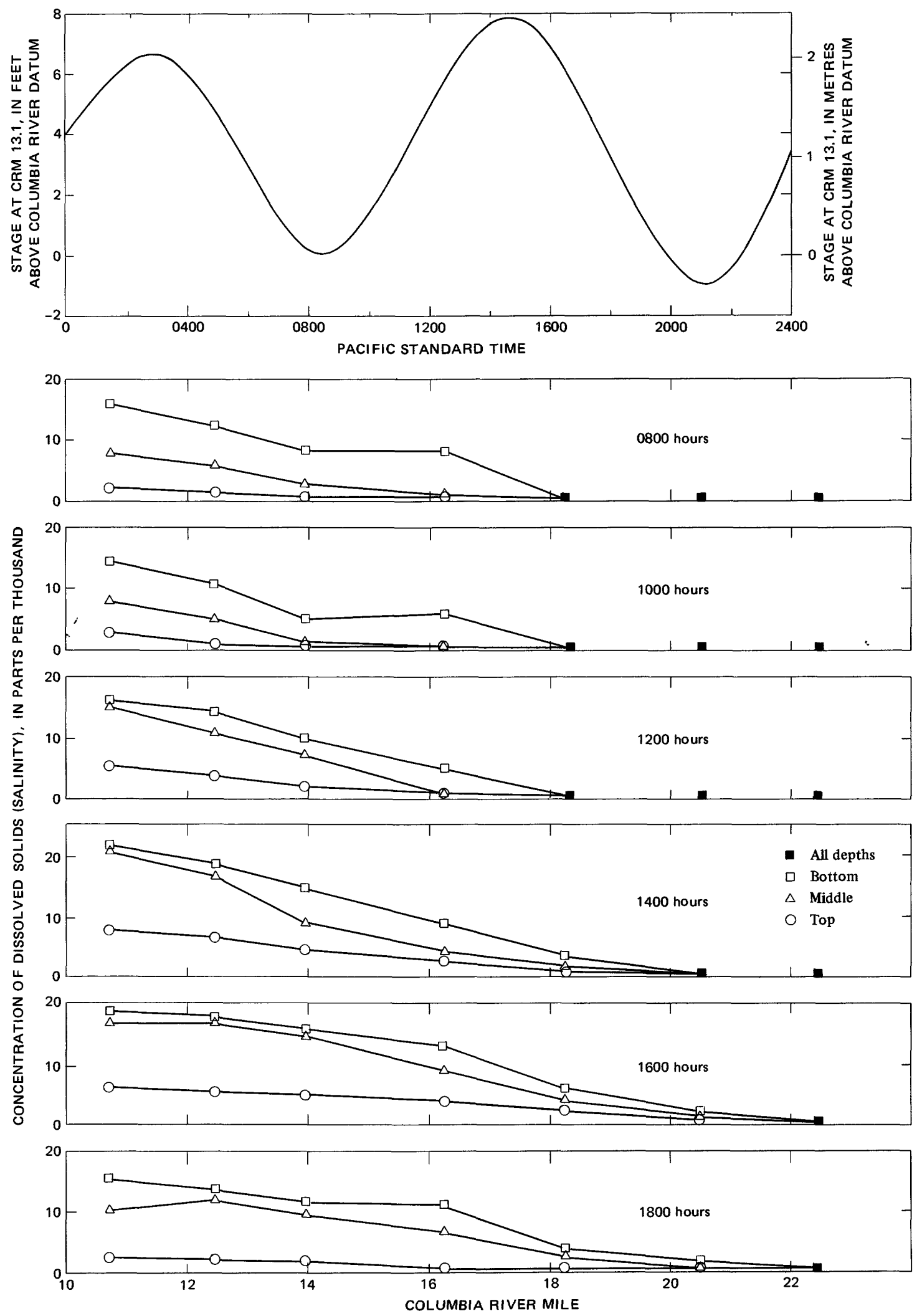

FIGIRE 16. - Salinity distribution along the longitudinal axis of the south channel at various times in the tidal cycle on September $14,1969$. 
end of the reach to 70 percent at the downstream end. At the top, the flow predominance remained approximately a constant 80 percent over the entire reach.

In both studies, the flow predominance was determined with velocity data for only half of the tidal cycle - the early morning ebb and the following flood. Tide ranges during these periods (figs. 16, 17) were such that the computed values of flow predominance on September 14 probably are lower than full-tidal-cycle values, and those computed for May 23 are higher. Despite this discrepancy, the data show that the point on the bed where the flow predominance is 50 percent (where the net flow is zero) varies longitudinally in response to the upland flow.

According to Simmons (1955), heaviest shoaling in partly mixed estuaries is between the high-tide and the low-tide positions of the upstream limit of saltwater intrusion, and flow predominance near the bottom in this zone is close to 50 percent. Shoaling occurs because the net downstream transport of sediment along the bottom is effectively stopped where there is a predominance of upstream currents and because suspended sediment tends to accumulate in the zone where net flow is near zero. This latter effect results from the tendency for sediment particles in the upper layers, where the flow is predominantly seaward, to settle during slack water into the lower layers where they are transported back upstream by the predominantly landward currents (fig. $13)$; this action over many tidal cycles causes an accumulation of sediment at and near the bed in the zone where neither upstream or downstream flow predominates. In the Columbia River estuary, much of the accumulated sediment is resuspended during the high-velocity period of each flood and ebb, thereby creating locally a "turbidity maximum" wherein the concentration of suspended sediment is considerably higher than it is either upstream or downstream (Hubbell and others, 1971).

Salinity data from the two longitudinal studies (figs. $16,17)$ show that on September 14, during the time for which flow predominance was computed, saltwater intrusion ranged between about CRM 18 and CRM 21; on May 23 it varied between about CRM 5 and CRM 14. On the basis of these data, shoaling would be expected in the reach between CRM 5 and 21. In confirmation, Lockett (1967) pointed out that in the $11-$ mile $(17.7-\mathrm{km})$ reach from Tongue Point (CRM 17.5) to Sand Island (CRM $6.5)$ there has been 77 million cubic yards $\left(59\right.$ million $\left.\mathrm{m}^{3}\right)$ of material dredged from the navigational channel during 1868 to 1958.

\section{SUMMARY}

Unsteady flow, caused mainly by tides, and complex velocity distributions, due mainly to salinity gradients, precluded use of conventional methods of measuring discharge and of computed discharge records in the Columbia River estuary. However, discharge data were obtained by employing a moving-boat technique (MOVD) in which both the direction and magnitude of the water velocity are measured throughout the entire depth at a series of laterally spaced verticals in a cross section. Data from repetitive measurements at Astoria and the Beaver Army Terminal during half tidal cycles (about 10 hours) were used to define flow hydrographs at these locations, and the hydrographs, in turn, were used to adapt and calibrate one-dimensional mathematical models for calculating continuous records of discharge. The discharge models for both Beaver Army Terminal and Astoria were based on solution of partial differential equations that express the conservation of mass and momentum in one-dimensional unsteady homogeneousdensity open-channel flow according to the method of characteristics (Lai, 1965a) using measured watersurface slopes and channel geometry as boundary conditions.

The mathematical model for the Beaver Army Terminal, which is in the freshwater part of the estuary at CRM 53.3, was used to compute instantaneous discharges every 15 minutes; daily mean discharges, in turn, were determined from these values. The flowresistance coefficient, $\eta$, in the model varied with discharge and was lowest at high flows. Discharges computed for the period May 1968 through June 1970 show that flow reversals at Beaver commonly occur during at least one of the twice-daily flood periods whenever the daily mean discharge is less than $185,000 \mathrm{ft}^{3} / \mathrm{s}(5,240$ $\mathrm{m}^{3} / \mathrm{s}$ ). For daily mean discharges of 185,000 to 225,000 $\mathrm{ft}^{3} / \mathrm{s}\left(5,240\right.$ to $\left.6,370 \mathrm{~m}^{3} / \mathrm{s}\right)$, the flow reverses occasionally during the strongest flood period, and for daily mean discharges greater than $225,000 \mathrm{ft}^{3} / \mathrm{s}\left(6,370 \mathrm{~m}^{3} / \mathrm{s}\right)$ the flow rarely reverses.

At Astoria (CRM 14), application of the basic onedimensional model was complicated because of the complex geometry of the reach and the presence of both longitudinal and lateral salinity gradients. To obtain, with the model, hydrographs having an overall shape that corresponded to measured hydrographs, it was necessary to vary $\eta$ throughout each flood and ebb period. In addition, in order to compute hydrographs that compared closely with measured hydrographs, a factor had to be applied daily to adjust the measured water-surface slopes. The required factor for each day of record was established by adjusting the slopes by trial until the daily mean discharge calculated from the instantaneous discharges computed every 15 minutes by the mathematical model agreed within a few percent of the daily mean discharges determined from a simple volumetric model. Because monthly mean discharges determined with daily mean discharges from the 

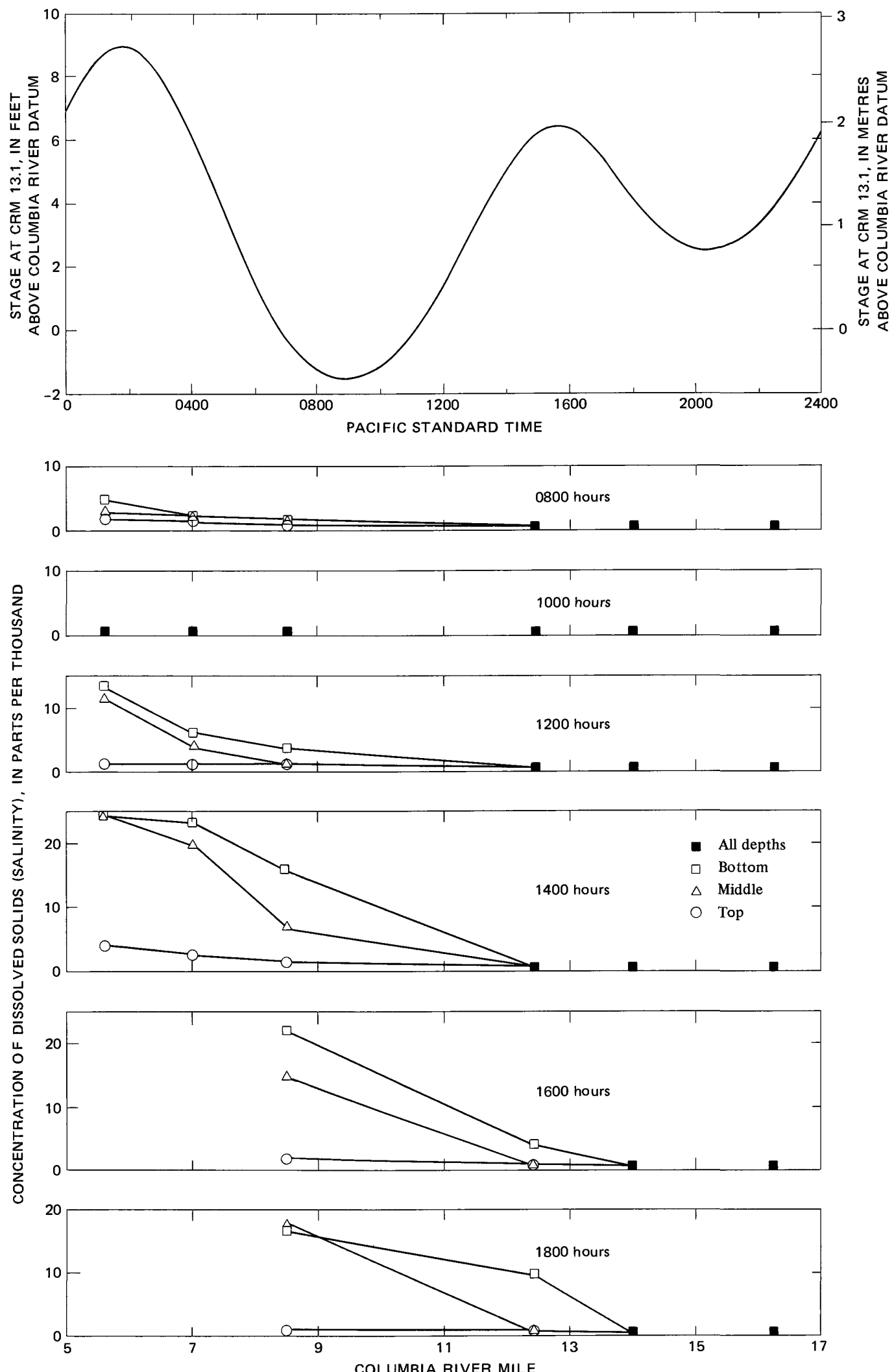

FIGURE 17. - Salinity distribution along the longitudinal axis of the south channel at various times in the tidal cycle on May 23,1970 . 
volumetric model compared within 5 percent of monthly mean discharges computed by the routing technique used by the Northwest Resorces Data Center (Orem, 1968), instantaneous discharge computed every 15 minutes with the mathematical model for the period March 1968 through June 1970 are considered to be fairly accurate.

Observations at Astoria indicate that near the surface, ebb velocities are as much as $8 \mathrm{ft} / \mathrm{s}(2.4 \mathrm{~m} / \mathrm{s})$ and flood velocities are as much as $6 \mathrm{ft} / \mathrm{s}(1.8 \mathrm{~m} / \mathrm{s})$. Time-averaged velocities in the cross section during each ebb and flood period, however, are about 3 and $2 \mathrm{ft} / \mathrm{s}(0.9$ and $0.6 \mathrm{~m} / \mathrm{s})$, respectively. Because of the relatively large upland flow and moderate tide range, instantaneous ebb discharges frequently are greater than 2 million $\mathrm{ft}^{3} / \mathrm{s}(0.06$ million $\mathrm{m}^{3} / \mathrm{s}$ ) and instantaneous flood discharges often are over 1.5 million $\mathrm{ft}^{3} / \mathrm{s}\left(0.04\right.$ million $\left.\mathrm{m}^{3} / \mathrm{s}\right)$.

Daily mean discharges at Astoria fluctuate cyclically because of (1) the daily 50 -minute shift in the position of the tide curve relative to absolute clock time, due to the difference in the length of lunar (24.8 hours) and solar (24.0 hours) days; and (2) the periodic variations in the maximum and minimum tide heights that occur with a frequency of about 14.3 days. Because of this cyclic pattern, daily mean discharges at Astoria are not a measure of the upland freshwater discharge. For instance, on September 22, 1969, the daily mean discharge at Beaver was about $100,000 \mathrm{ft}^{3} / \mathrm{s}\left(2,830 \mathrm{~m}^{3} / \mathrm{s}\right)$ downstream, but at Astoria it was $7,400 \mathrm{ft}^{3} / \mathrm{s}\left(210 \mathrm{~m}^{3} / \mathrm{s}\right)$ upstream.

Based on the change in the proportion of flow through the north (northernmost channel and shallow midestuary area combined) and south channels at CRM 14 during ebbs and floods, for daily mean discharges at Beaver of less than about $165,000 \mathrm{ft}^{3} / \mathrm{s}\left(4,670 \mathrm{~m}^{3} / \mathrm{s}\right)$ there is a net clockwise circulation in the lower estuary. That is, the proportion of the total quantity of water flowing upstream in the north channel during the flood is greater than the proportion of the total quantity of water flowing downstream during the ebb, whereas the reverse occurs in the south channel. For daily mean discharges from 165,000 to about $190,000 \mathrm{ft}^{3} / \mathrm{s}\left(4,670\right.$ to about $\left.5,380 \mathrm{~m}^{3} / \mathrm{s}\right)$ the net circulation is counterclockwise, and for discharges greater than $190,000 \mathrm{ft}^{3} / \mathrm{s}\left(5,380 \mathrm{~m}^{3} / \mathrm{s}\right)$ it is also clockwise. On the average, the north channel conveys 76 percent of the flood flow and 69 percent of the ebb flow.

At the measuring cross section at Astoria, flow near the bottom in the "north" (northernmost) channel is predominantly landward for mean discharges (algebraic mean throughout a tidal cycle) less than about 340,000 $\mathrm{ft}^{3} / \mathrm{s}\left(9,630 \mathrm{~m}^{3} / \mathrm{s}\right)$, whereas from middepth to the surface it is predominantly seaward with the highest predominance being near the surface. At a mean discharge of $550,000 \mathrm{ft}^{3} / \mathrm{s} \quad\left(15,600 \mathrm{~m}^{3} / \mathrm{s}\right)$, the flow predominance at all depths is about 77 percent. In the south channel, the flow-predominance pattern is very similar to that of the "north" channel. Near the bottom the flow is predominantly landward for mean discharges less than $260,000 \mathrm{ft}^{3} / \mathrm{s}\left(7,360 \mathrm{~m}^{3} / \mathrm{s}\right)$, and in the upper half of the depth the flow is predominantly seaward, with the highest predominance near the surface. At a mean discharge of $700,000 \mathrm{ft}^{3} / \mathrm{s} \quad\left(19,800 \mathrm{~m}^{3} / \mathrm{s}\right)$, the flow predominance at all depths is about 92 percent. It is estimated that the flow predominance in the "north" and south channels would reach 100 percent seaward at a discharge of about 1 million $\mathrm{ft}^{3} / \mathrm{s}\left(0.03\right.$ million $\left.\mathrm{m}^{3} / \mathrm{s}\right)$. The direction of flow in the "north" and south channels is parallel to the riverbank, but the direction of flow in the middle channel trends in a diagonal direction, and the channel is not well defined. As a result, in the middle channel, at the bottom, flow predominance is seaward for mean discharges less than $115,000 \mathrm{ft}^{3} / \mathrm{s}\left(3,260 \mathrm{~m}^{3} / \mathrm{s}\right)$ and landward for discharges from 115,000 to $425,000 \mathrm{ft}^{3} / \mathrm{s}$ $\left(3,260\right.$ to $\left.12,000 \mathrm{~m}^{3} / \mathrm{s}\right)$. At 25 percent of the depth, flow predominance is landward for discharges less than $120,000 \mathrm{ft}^{3} / \mathrm{s}\left(3,400 \mathrm{~m}^{3} / \mathrm{s}\right)$ but is seaward for higher flows. In the upper half of the depth, the flow predominance is seaward and increases as the discharge increases. At a mean discharge of about $450,000 \mathrm{ft}^{3} / \mathrm{s}\left(12,700 \mathrm{~m}^{3} / \mathrm{s}\right)$, the flow predominance at all depths is about 70 percent.

Longitudinal flow characteristics in the south channel determined when the daily mean discharge at Astoria was $208,000 \mathrm{ft}^{3} / \mathrm{s}\left(5,890 \mathrm{~m}^{3} / \mathrm{s}\right.$; Sept. 14, 1969), indicated that flow at all depths was predominantly seaward upstream of CRM 17.5. At CRM 17.5, flow predominance near the bottom became landward while the flow in the upper layers remained seaward. Salinity data showed that during the day the upstream extent of saltwater instrusion ranged between about CRM 18 and CRM 21 . For a daily mean discharge at Astoria of $437,000 \mathrm{ft}^{3} / \mathrm{s}$ $\left(12,400 \mathrm{~m}^{3} / \mathrm{s}\right.$; May 23,1970$)$, the flow was predominantly seaward at all depths throughout the entire study reach, which extended from CRM 5.6 to 16.2 . During the day saltwater intrusion extended upstream to CRM 14 and receded to about CRM 5. On the basis of these data, heavy shoaling should occur in the reach between CRM 5 and 21; dredging records of the U.S. Army Corps of Engineers confirm that this is the case.

\section{REFERENCES CITED}

Baltzer, R. A., and Lai, Chintu, 1968, Computer simulation of unsteady flows in waterways: Am. Soc. Civil Engineers, Hydraulics Div. Jour., v. 94, no. HY4, Proc. Paper 6048, p. 1083-1117.

Baltzer, R. A., and Shen, John, 1961, Flows of homogeneous density in tidal reaches: U.S. Geol. Survey open-file report, $107 \mathrm{p}$.

Barron, E. G., 1963, New instruments for surface-water investigations, in Selected techniques in water resources investigations, compiled by G. N. Mesnier, and K. T. Iseri: U.S. Geol. Survey WaterSupply Paper 1669-Z, p. Z1-Z12.

Davidian, Jacob, 1964, Computation of discharge in tidal reaches: U.S Geol. Survey Surface Water Techniques, book 1, chap. 2, 49 p. 
Dixon, W. J., and Massey, F. J., Jr., 1957, Introduction to statistical analysis [2d ed.]: New York, McGraw-Hill Book Co., p. 130.

Hansen, D. V., 1965, Currents and mixing in the Columbia River estuary, in Ocean Science and Ocean Engineering: Marine Technology and Am. Soc. Limnology and Oceanography Joint Conf., Washington, D.C., June 1965, Trans., p. 943-955.

Hubbell, D. W., Glenn, J. L., and Stevens, H. H., Jr., 1971, Studies of sediment transport in the Columbia River estuary: Tech. Conf. on Estuaries of the Pacific Northwest, Oregon State Univ., Corvallis, 1971, Proc. Circ. 42, p. 190-226.

Lai, Chintu, 1965a, Flows of homogeneous density in tidal reaches, solution by the method of characteristics: U.S. Geol. Survey openfile report, $58 \mathrm{p}$.

$1965 \mathrm{~b}$, Flows of homogeneous density in tidal reaches, solution by the implicit method: U.S. Geol. Survey open-file report, $43 \mathrm{p}$.

1967, Computation of transient flows in rivers and estuaries by the multiple-reach method of characteristics, in Geological Survey Research 1967: U.S. Geol. Survey Prof. Paper 575-D, p. D273-D280.

Lockett, J. B., 1967, Sediment transport and diffusion: Columbia River estuary and entrance: Am. Soc. Civil Engineers, Waterways and Harbors Div. Jour., v. 93, no. WW4, Proc. Paper 5601, p. 167-175.

Lockett, J. B., and Kidby, H. A., 1961, Prototype measurements of the Columbia River estuary: Am. Soc. Civil Engineers, Hydraulics Div. Jour., v. 87, no. HY1, Proc. Paper 2710, p. 57-83.

Orem, H. M., 1968, Discharge in the lower Columbia River basin, 1928-65: U.S. Geol. Survey Circ. 550, 24 p.
Pritchard, D. W., 1955, Estuarine circulation patterns: Am. Soc. Civil Engineers Proc., v. 81, Paper 717, 11 p.

Prych, E. A., Hubbell, D. W., and Glenn, J. L., 1967, New estuarine measurement equipment and techniques: Am. Soc. Civil Engineers, Waterways and Harbors Div. Jour., v. 93, no. WW2, Proc. Paper 5219, p. 41-58.

Savini, John, and Bodhaine, G. L., 1971, Analysis of current-meter data at Columbia River gaging stations, Washington and Oregon: U.S. Geol. Survey Water-Supply Paper 1869-F, 59 p.

Simmons, H. B., 1955, Some effects of upland discharge on estuarine hydraulics: Am. Soc. Civil Engineers Proc., v. 81, Paper 792, 20 p.

Smoot, G. F., and Novak, C. E., 1969, Measurement of discharge by the moving-boat method: U.S. Geol. Survey Techniques Water Resources Inv., book 3, chap. A11, 24 p.

U.S. Army Corps of Engineers, 1960, Interim report on 1959 current measuring program Columbia River at mouth, Oregon and Washington: v. I-IV.

U.S. Coast and Geodetic Survey, 1969, Tide tables high and low water predictions, 1970, west coast of North and South American including the Hawaiian Islands: Washington, U.S. Govt. Printing Office, p. 172-173.

U.S. Geological Survey, 1970, Surface water records, part 1 of Water resources data for Oregon, 1969: Portland, Oreg., Water Resources Div., U.S. Geol. Survey, 367 p.

1971, Surface water records, part 1 of Water resources data for Oregon, 1970: Portland, Oreg., Water Resources Div., U.S. Geol. Survey, 378 p. 
DISCHARGE AND FLOW DISTRIBUTION, COLUMBIA RIVER ESTUARY

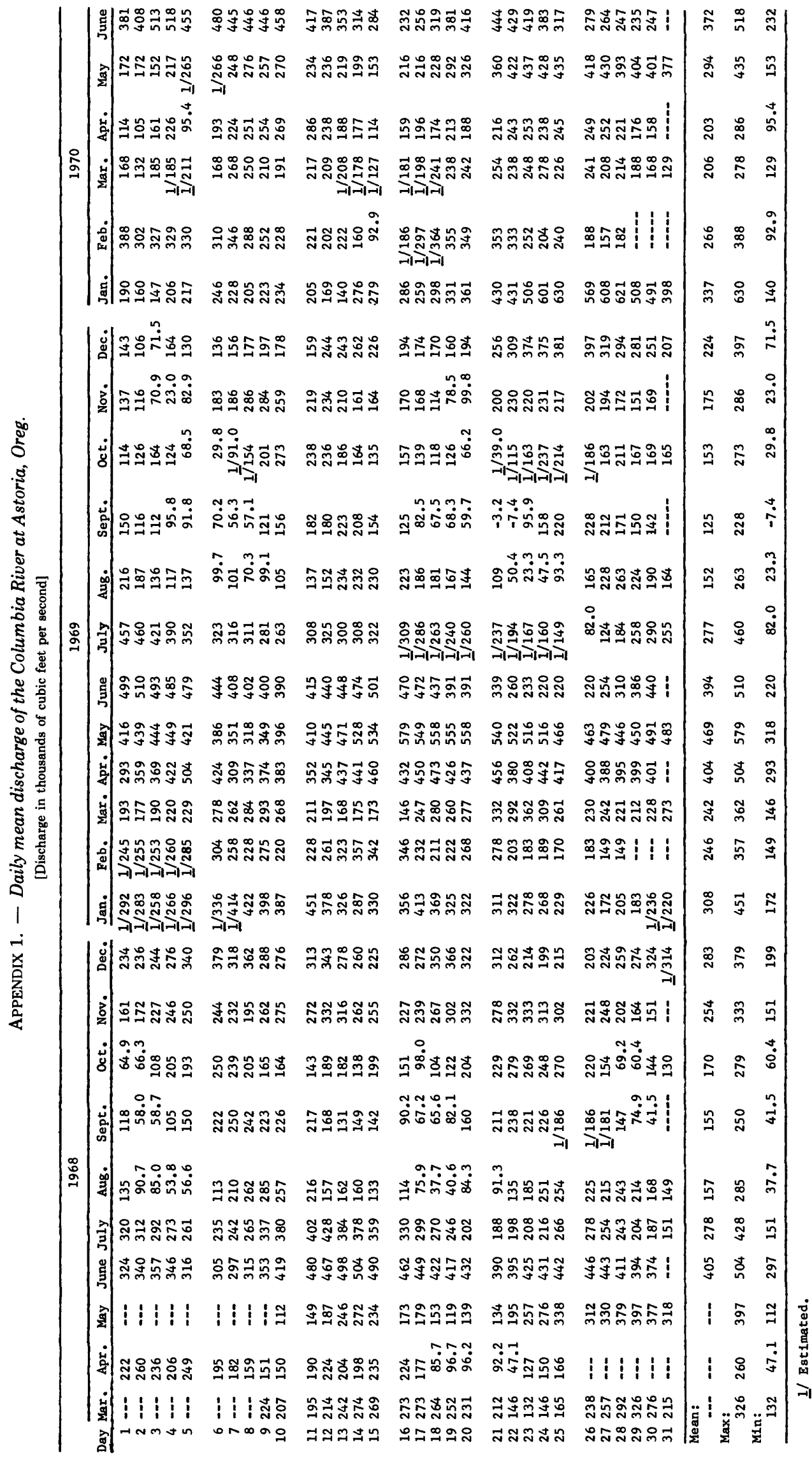




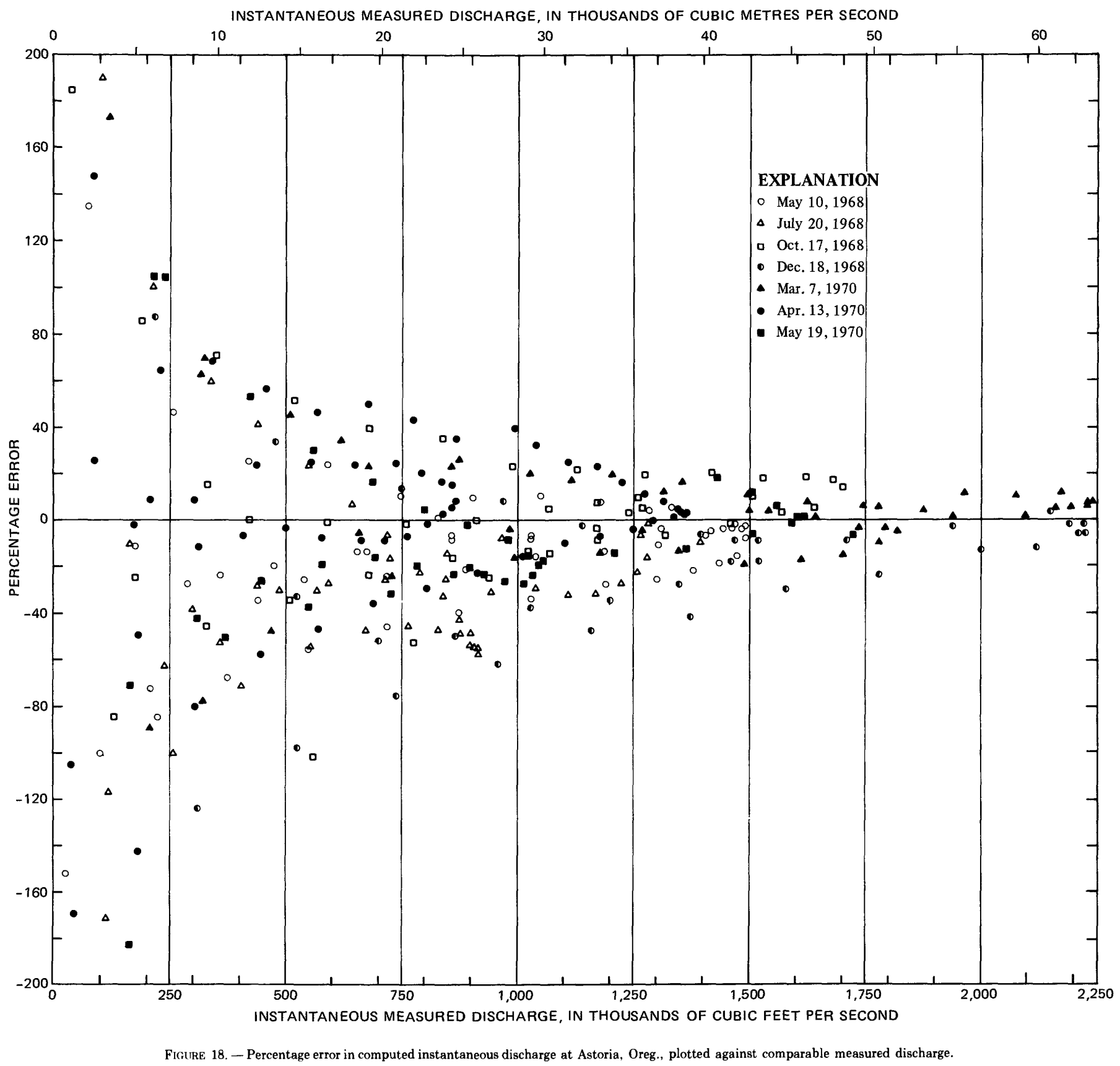

APPENDIX 2. - DETERMINATION OF PERCENTAGE ERROR BETWEEN MEASURED AND COMPUTED DISCHARGES AT ASTORIA

In order to evaluate the accuracy of the mathematical model for computing instantaneous discharges at Astoria, differences between discharges determined every 15 minutes and comparable discharges from the measured hydrographs have been analyzed statistically to define the "tolerance interval" (Dixon and Massey, 1957 , p. 130), which indicates with a specified confidence the proportion of a population of computed discharges that have an error (difference) equal to or less than a specified value. The tolerance interval is expressed as

$$
\bar{y} \pm K s,
$$

where

$\bar{y}$ is the mean error of a sample from the population;

$K$ is the tolerance factor for a normal distribution and depends on the specified proportion of the population, sample size, and confidence coefficient; and

$s$ is the standard deviation of the sample errors. Figure 18 shows the percent error in computed dis- 
charges plotted against the corresponding measured discharges for all hydrographs used in the calibration of the mathematical model. This graph demonstrates that the distribution of plus and minus errors is roughly symmetrical about the zero-error line and that the scatter decreases as the discharge increases. In order to eliminate the influence of discharge from the statistical analysis, the errors were divided into 10 ranges according to discharge, and values within each range were treated as an independent set of data. In addition, several sets of data were examined to confirm that the distribution of errors within any set approximately follows the normal error curve-a requirement for the use of $K$.
Results from the analysis are presented in table 7 . The tolerance limits define the end points of the tolerance interval and indicate, with 90 percent confidence, the percentage error that will not be equaled or exceeded by more than 10 percent of all computed discharges in a discharge range. Although errors are large when discharges are low, table 7 shows that for discharges greater than $1,250,000 \mathrm{ft}^{3} / \mathrm{s}\left(35,400 \mathrm{~m}^{3} / \mathrm{s}\right)$, which occur about 30 percent of the time, 90 percent of all instantaneous discharges might be expected to be in error less than about 25 percent.

TABLE 7. - Error analysis of computed discharges at Astoria, Oreg.

[Values are based on percentage errors].

\begin{tabular}{|c|c|c|c|c|c|c|}
\hline \multirow[b]{2}{*}{$\underset{\left(f^{2} / \mathbf{s}\right)}{\text { Discharge range }}$} & \multirow{2}{*}{$\begin{array}{c}\text { Number } \\
\text { of } \\
\text { obser- } \\
\text { vations }\end{array}$} & \multirow{2}{*}{$\begin{array}{c}\text { Mean } \\
\text { percent- } \\
\text { age } \\
\text { error } \\
(\bar{y})\end{array}$} & \multirow[b]{2}{*}{$\mathrm{K}^{2}$} & \multirow{2}{*}{$\begin{array}{c}\text { Standard } \\
\text { deviation } \\
(\mathbf{s})\end{array}$} & \multicolumn{2}{|c|}{ Tolerance limits } \\
\hline & & & & & $\begin{array}{l}\text { Lower } \\
\text { limit }\end{array}$ & $\begin{array}{l}\text { Upper } \\
\text { limit }\end{array}$ \\
\hline $\begin{array}{r}0-225,000 \\
226,000-\quad 500,000 \\
501,000-750,000 \\
751,000-1,000,000 \\
1,000,1,000-1,250,000 \\
1,251,000-1,500,000 \\
1,5001,1,000-1,750,000 \\
1,751,000-2,000,000 \\
2,7001,1000-2,250,000 \\
2,251,000-2,500,000\end{array}$ & $\begin{array}{l}38 \\
43 \\
51 \\
57 \\
45 \\
51 \\
24 \\
11 \\
12 \\
3\end{array}$ & $\begin{array}{r}102.1 \\
-0.6 \\
-7.6 \\
-10.9 \\
-5.4 \\
-2.2 \\
1.6 \\
-3.3 \\
1.7 \\
7.7\end{array}$ & $\begin{array}{l}1.971 \\
1.945 \\
1.913 \\
1.895 \\
1.935 \\
1.913 \\
2.089 \\
2.463 \\
2.404 \\
5.847\end{array}$ & $\begin{array}{r}408.5 \\
62.5 \\
39.3 \\
29.8 \\
21.5 \\
13.4 \\
12.3 \\
9.7 \\
6.8 \\
1.5\end{array}$ & $\begin{array}{r}-703.1 \\
-122.2 \\
-82.8 \\
-67.4 \\
-47.0 \\
-27.8 \\
-24.1 \\
-27.2 \\
-14.6 \\
-1.1\end{array}$ & $\begin{array}{r}907.2 \\
121.0 \\
67.6 \\
45.6 \\
36.2 \\
23.4 \\
27.3 \\
20.6 \\
18.0 \\
16.5\end{array}$ \\
\hline
\end{tabular}

'Pertains to both ebb and flood discharges.
2Tolerance factor for normal distribution which defines with 90-percent confidence an interval about the sample mean that includes 90 percent of the population. (From Dixon and Massey, 1957, table A-16.) 
